\title{
Dopamine receptors (version 2019.4) in the IUPHAR/BPS Guide to Pharmacology Database
}

\author{
Jean-Martin Beaulieu ${ }^{1}$, Emiliana Borrelli ${ }^{2}$, Arvid Carlsson ${ }^{3}$, Marc G. Caron ${ }^{4}$, Olivier Civelli ${ }^{5}$, Stefano Espinoza ${ }^{6}$, \\ Gilberto Fisone ${ }^{7}$, Raul R. Gainetdinov ${ }^{8}$, David K. Grandy ${ }^{9}$, John W. Kebabian ${ }^{10}$, Saloman Z. Langer ${ }^{11}$, Maria \\ Cristina Missale ${ }^{12}$, Kim A. Neve ${ }^{9}$, Bernard Scatton ${ }^{13}$, Jean-Charles Schwartz ${ }^{14}$, Goran Sedvall ${ }^{7}$, Philip \\ Seeman ${ }^{1}$, David R. Sibley ${ }^{15}$, Pierre Sokoloff ${ }^{14}$, Pierre F. Spano ${ }^{16}$ and Hubert H. M. Van Tol \\ 1. University of Toronto, Canada \\ 2. University of California Irvine, USA \\ 3. University of Göteborg, Sweden \\ 4. Duke University, USA \\ 5. University of California at Irvine, USA \\ 6. Istituto Italiano di Tecnologia, Italy \\ 7. Karolinska Institutet, Sweden \\ 8. St. Petersburg State University, Russia \\ 9. Oregon Health \& Science University, USA \\ 10. Research Biochemical Incorporated, USA \\ 11. Compugen, Israel \\ 12. University of Brescia, Italy \\ 13. Sanofi Synthelabo Recherche, France \\ 14. INSERM, France \\ 15. National Institutes of Health, USA \\ 16. Universitâ degli Studi di Brescia, Italy
}

\begin{abstract}
Dopamine receptors (nomenclature as agreed by the NC-IUPHAR Subcommittee on Dopamine Receptors [363]) are commonly divided into $D_{1}$-like $\left(D_{1}\right.$ and $\left.D_{5}\right)$ and $D_{2}$-like $\left(D_{2}, D_{3}\right.$ and $\left.D_{4}\right)$ families, where the endogenous agonist is dopamine.

\section{Contents}

This is a citation summary for Dopamine receptors in the Guide to Pharmacology database (GtoPdb). It exists purely as an adjunct to the database to facilitate the recognition of citations to and from the database by citation analyzers. Readers will almost certainly want to visit the relevant sections of the database which are given here under database links.

GtoPdb is an expert-driven guide to pharmacological targets and the substances that act on them. GtoPdb is a reference work which is most usefully represented as an on-line database. As in any publication this work should be appropriately cited, and the papers it cites should also be recognized. This document provides a citation for the relevant parts of the database, and also provides a reference list for the research cited by those
\end{abstract}


parts.

Please note that the database version for the citations given in GtoPdb are to the most recent preceding version in which the family or its subfamilies and targets were substantially changed. The links below are to the current version. If you need to consult the cited version, rather than the most recent version, please contact the GtoPdb curators.

\section{Database links}

Dopamine receptors

http://www.guidetopharmacology.org/GRAC/FamilyDisplayForward?familyld=20

Introduction to Dopamine receptors

http://www.guidetopharmacology.org/GRAC/FamilyIntroductionForward?familyld=20

Receptors

$D_{1}$ receptor

http://www.guidetopharmacology.org/GRAC/ObjectDisplayForward?objectld=214

$\mathrm{D}_{2}$ receptor

http://www.guidetopharmacology.org/GRAC/ObjectDisplayForward?objectld=215

$D_{3}$ receptor

http://www.guidetopharmacology.org/GRAC/ObjectDisplayForward?objectld=216

$\mathrm{D}_{4}$ receptor

http://www.guidetopharmacology.org/GRAC/ObjectDisplayForward?objectld=217

$\mathrm{D}_{5}$ receptor

http://www.guidetopharmacology.org/GRAC/ObjectDisplayForward?objectld=218

\section{References}

1. Accili D, Fishburn CS, Drago J, Steiner H, Lachowicz JE, Park BH, Gauda EB, Lee EJ, Cool MH and Sibley DR et al.. (1996) A targeted mutation of the D3 dopamine receptor gene is associated with hyperactivity in mice. Proc. Natl. Acad. Sci. U.S.A. 93: 1945-9 [PMID:8700864]

2. Agai-Csongor E, Domány G, Nógrádi K, Galambos J, Vágó I, Keserű GM, Greiner I, Laszlovszky I, Gere A and Schmidt E et al.. (2012) Discovery of cariprazine (RGH-188): a novel antipsychotic acting on dopamine D3/D2 receptors. Bioorg. Med. Chem. Lett. 22: 3437-40 [PMID:22537450]

3. Ahlenius S and Salmi P. (1994) Behavioral and biochemical effects of the dopamine D3 receptor-selective ligand, 7-OH-DPAT, in the normal and the reserpine-treated rat. Eur. J. Pharmacol. 260: 177-81 [PMID:7988642]

4. Akunne HC, Towers P, Ellis GJ, Dijkstra D, Wikström H, Heffner TG, Wise LD and Pugsley TA. (1995) Characterization of binding of [3H]PD 128907, a selective dopamine D3 receptor agonist ligand, to $\mathrm{CHO}$ K1 cells. Life Sci. 57: 1401-10 [PMID:7674830]

5. Al Hussainy R, Verbeek J, van der Born D, Braker AH, Leysen JE, Knol RJ, Booij J and Herscheid JK. (2011) Design, synthesis, radiolabeling, and in vitro and in vivo evaluation of bridgehead iodinated analogues of $\mathrm{N}$-\{2-[4-(2-methoxyphenyl)piperazin-1-yl]ethyl\}-N-(pyridin-2-yl)cyclohexanecarboxamide (WAY-100635) as potential SPECT ligands for the 5-HT1A receptor. J. Med. Chem. 54: 3480-91 [PMID:21520940]

6. Albert PR, Neve KA, Bunzow JR and Civelli O. (1990) Coupling of a cloned rat dopamine-D2 receptor to inhibition of adenylyl cyclase and prolactin secretion. J. Biol. Chem. 265: 2098-104 [PMID:1688845]

7. Allen JA, Yost JM, Setola V, Chen X, Sassano MF, Chen M, Peterson S, Yadav PN, Huang XP and Feng $B$ et al.. (2011) Discovery of $\beta$-arrestin-biased dopamine D2 ligands for probing signal transduction pathways essential for antipsychotic efficacy. Proc. Natl. Acad. Sci. U.S.A. 108: 18488-93 [PMID:22025698]

8. Amenta F, Chiandussi L, Mancini M, Ricci A, Schena M and Veglio F. (1994) Pharmacological 
characterization and autoradiographic localization of dopamine receptors in the human adrenal cortex. Eur. J. Endocrinol. 131: 91-6 [PMID:8038912]

9. Amenta F, Collier WL and Ricci A. (1990) Autoradiographic localization of vascular dopamine receptors. Am. J. Hypertens. 3: 34S-36S [PMID:2200435]

10. Amenta F and Ricci A. (1990) Autoradiographic localization of dopamine DA-1 receptors in the rat renal vasculature using [3H]-SCH 23390 as a ligand. J Auton Pharmacol 10: 373-83 [PMID:2151196]

11. Amenta F, Ricci A and Vega JA. (1990) Pharmacological characterization of rat renal medulla dopaminesensitive cyclic adenosine monophosphate generating system. J. Pharmacol. Exp. Ther. 253: 246-9 [PMID:2158544]

12. An JJ, Bae MH, Cho SR, Lee SH, Choi SH, Lee BH, Shin HS, Kim YN, Park KW and Borrelli Eet al.. (2004) Altered GABAergic neurotransmission in mice lacking dopamine D2 receptors. Mol. Cell. Neurosci. 25: $732-41$ [PMID:15080900]

13. Andersen PH and Jansen JA. (1990) Dopamine receptor agonists: selectivity and dopamine D1 receptor efficacy. Eur. J. Pharmacol. 188: 335-47 [PMID:1973652]

14. Andreoli M, Tessari M, Pilla M, Valerio E, Hagan JJ and Heidbreder CA. (2003) Selective antagonism at dopamine $\mathrm{D} 3$ receptors prevents nicotine-triggered relapse to nicotine-seeking behavior. Neuropsychopharmacology 28: 1272-80 [PMID:12700694]

15. Angers S, Salahpour A and Bouvier M. (2002) Dimerization: an emerging concept for G protein-coupled receptor ontogeny and function. Annu. Rev. Pharmacol. Toxicol. 42: 409-35 [PMID:11807178]

16. Antonipillai I, Broers MI and Lang D. (1989) Evidence that specific dopamine-1 receptor activation is involved in dopamine-induced renin release. Hypertension 13: 463-8 [PMID:2566577]

17. Aperia A and Greengard P. (2006) Dopamine receptor response to NMDA stimulation.Am J Psychiatry 163: 1682 [PMID:17012674]

18. Araki K, Kuwano R, Morii K, Hayashi S, Minoshima S, Shimizu N, Katagiri T, Usui H, Kumanishi T and Takahashi Y. (1992) Structure and expression of human and rat D2 dopamine receptor genes. Neurochem. Int. 21: 91-8 [PMID:1363862]

19. Aretha CW, Sinha A and Galloway MP. (1995) Dopamine D3-preferring ligands act at synthesis modulating autoreceptors. J. Pharmacol. Exp. Ther. 274: 609-13 [PMID:7636720]

20. Ariano MA, Stromski CJ, Smyk-Randall EM and Sibley DR. (1992) D2 dopamine receptor localization on striatonigral neurons. Neurosci. Lett. 144: 215-20 [PMID:1436705]

21. Arias-Montaño JA, Floran B, Floran L, Aceves J and Young JM. (2007) Dopamine D(1) receptor facilitation of depolarization-induced release of gamma-amino-butyric acid in rat striatum is mediated by the cAMP/PKA pathway and involves P/Q-type calcium channels. Synapse 61: 310-9 [PMID:17318879]

22. Arnt J, Hyttel J and Sánchez C. (1992) Partial and full dopamine D1 receptor agonists in mice and rats: relation between behavioural effects and stimulation of adenylate cyclase activity in vitro. Eur. J. Pharmacol. 213: 259-67 [PMID:1355737]

23. Arnt $\mathrm{J}$ and Skarsfeldt T. (1998) Do novel antipsychotics have similar pharmacological characteristics? A review of the evidence. Neuropsychopharmacology 18: 63-101 [PMID:9430133]

24. Asa SL, Kelly MA, Grandy DK and Low MJ. (1999) Pituitary lactotroph adenomas develop after prolonged lactotroph hyperplasia in dopamine D2 receptor-deficient mice. Endocrinology 140: 5348-55 [PMID:10537166]

25. Asghari V, Sanyal S, Buchwaldt S, Paterson A, Jovanovic V and Van Tol HH. (1995) Modulation of intracellular cyclic AMP levels by different human dopamine D4 receptor variants. J. Neurochem. 65: 115765 [PMID:7643093]

26. Ashby Jr CR, Paul M, Gardner EL, Heidbreder CA and Hagan JJ. (2003) Acute administration of the selective D3 receptor antagonist SB-277011A blocks the acquisition and expression of the conditioned place preference response to heroin in male rats. Synapse 48: 154-6 [PMID:12645041]

27. Asico LD, Ladines C, Fuchs S, Accili D, Carey RM, Semeraro C, Pocchiari F, Felder RA, Eisner GM and Jose PA. (1998) Disruption of the dopamine D3 receptor gene produces renin-dependent hypertension. J. Clin. Invest. 102: 493-8 [PMID:9691085] 
28. Auerbach SS and DrugMatrix $\AA^{\circledR}$ and ToxFX ${ }^{\circledR}$ Coordinator National Toxicology Program.. National Toxicology Program: Dept of Health and Human Services.

29. Aujla $\mathrm{H}$ and Beninger RJ. (2005) The dopamine $\mathrm{D}(3)$ receptor-preferring partial agonist BP 897 dosedependently attenuates the expression of amphetamine-conditioned place preference in rats. Behav Pharmacol 16: 181-6 [PMID:15864073]

30. Baik JH, Picetti R, Saiardi A, Thiriet G, Dierich A, Depaulis A, Le Meur M and Borrelli E. (1995) Parkinsonian-like locomotor impairment in mice lacking dopamine D2 receptors. Nature 377: 424-8 [PMID:7566118]

31. Banala AK, Levy BA, Khatri SS, Furman CA, Roof RA, Mishra Y, Griffin SA, Sibley DR, Luedtke RR and Newman AH. (2011) N-(3-fluoro-4-(4-(2-methoxy or 2,3-dichlorophenyl)piperazine-1yl)butyl)arylcarboxamides as selective dopamine D3 receptor ligands: critical role of the carboxamide linker for D3 receptor selectivity. J. Med. Chem. 54: 3581-94 [PMID:21495689]

32. Baufreton J, Garret M, Rivera A, de la Calle A, Gonon F, Dufy B, Bioulac B and Taupignon A. (2003) D5 (not D1) dopamine receptors potentiate burst-firing in neurons of the subthalamic nucleus by modulating an L-type calcium conductance. J. Neurosci. 23: 816-25 [PMID:12574410]

33. Beaulieu JM, Espinoza S and Gainetdinov RR. (2015) Dopamine receptors - IUPHAR Review 13.Br. J. Pharmacol. 172: 1-23 [PMID:25671228]

34. Beaulieu JM and Gainetdinov RR. (2011) The physiology, signaling, and pharmacology of dopamine receptors. Pharmacol. Rev. 63: 182-217 [PMID:21303898]

35. Beaulieu JM, Marion S, Rodriguiz RM, Medvedev IO, Sotnikova TD, Ghisi V, Wetsel WC, Lefkowitz RJ, Gainetdinov RR and Caron MG. (2008) A beta-arrestin 2 signaling complex mediates lithium action on behavior. Cell 132: 125-36 [PMID:18191226]

36. Beaulieu JM, Sotnikova TD, Marion S, Lefkowitz RJ, Gainetdinov RR and Caron MG. (2005) An Akt/betaarrestin 2/PP2A signaling complex mediates dopaminergic neurotransmission and behavior. Cell 122: 26173 [PMID:16051150]

37. Beaulieu JM, Sotnikova TD, Yao WD, Kockeritz L, Woodgett JR, Gainetdinov RR and Caron MG. (2004) Lithium antagonizes dopamine-dependent behaviors mediated by an AKT/glycogen synthase kinase 3 signaling cascade. Proc. Natl. Acad. Sci. U.S.A. 101: 5099-104 [PMID:15044694]

38. Beaulieu JM, Tirotta E, Sotnikova TD, Masri B, Salahpour A, Gainetdinov RR, Borrelli E and Caron MG. (2007) Regulation of Akt signaling by D2 and D3 dopamine receptors in vivo. J. Neurosci. 27: 881-5 [PMID:17251429]

39. Bek MJ, Wang X, Asico LD, Jones JE, Zheng S, Li X, Eisner GM, Grandy DK, Carey RM and Soares-daSilva $P$ et al.. (2006) Angiotensin-II type 1 receptor-mediated hypertension in D4 dopamine receptordeficient mice. Hypertension 47: 288-95 [PMID:16380537]

40. Benoit-Marand M, Borrelli E and Gonon F. (2001) Inhibition of dopamine release via presynaptic D2 receptors: time course and functional characteristics in vivo. J. Neurosci. 21: 9134-41 [PMID:11717346]

41. Bergman J, Roof RA, Furman CA, Conroy JL, Mello NK, Sibley DR and Skolnick P. (2013) Modification of cocaine self-administration by buspirone (buspar $\AA$ ): potential involvement of D3 and D4 dopamine receptors. Int. J. Neuropsychopharmacol. 16: 445-58 [PMID:22827916]

42. Berlanga ML, Simpson TK and Alcantara AA. (2005) Dopamine D5 receptor localization on cholinergic neurons of the rat forebrain and diencephalon: a potential neuroanatomical substrate involved in mediating dopaminergic influences on acetylcholine release. J. Comp. Neurol. 492: 34-49 [PMID:16175554]

43. Berry CB, Bubser M, Jones CK, Hayes JP, Wepy JA, Locuson CW, Daniels JS, Lindsley CW and Hopkins CR. (2014) Discovery and Characterization of ML398, a Potent and Selective Antagonist of the D4 Receptor with in Vivo Activity. ACS Med Chem Lett 5: 1060-4 [PMID:25221667]

44. Bertorello $A$ and Aperia A. (1990) Inhibition of proximal tubule $\mathrm{Na}(+)-\mathrm{K}(+)$-ATPase activity requires simultaneous activation of DA1 and DA2 receptors. Am. J. Physiol. 259: F924-8 [PMID:1979719]

45. Bertorello AM, Hopfield JF, Aperia A and Greengard P. (1990) Inhibition by dopamine of $(\mathrm{Na}(+)+\mathrm{K}+)$ ATPase activity in neostriatal neurons through $\mathrm{D} 1$ and $\mathrm{D} 2$ dopamine receptor synergism. Nature 347: 386-388 [PMID:1977083] 
46. Blom H, Rönnlund D, Scott L, Spicarova Z, Rantanen V, Widengren J, Aperia A and Brismar H. (2012) Nearest neighbor analysis of dopamine $\mathrm{D} 1$ receptors and $\mathrm{Na}(+)-\mathrm{K}(+)$-ATPases in dendritic spines dissected by STED microscopy. Microsc. Res. Tech. 75: 220-8 [PMID:21809413]

47. Bonito-Oliva A, Pallottino S, Bertran-Gonzalez J, Girault JA, Valjent E and Fisone G. (2013) Haloperidol promotes mTORC1-dependent phosphorylation of ribosomal protein $\mathrm{S} 6$ via dopamine- and CAMPregulated phosphoprotein of $32 \mathrm{kDa}$ and inhibition of protein phosphatase-1. Neuropharmacology 72: 197203 [PMID:23643747]

48. Booze RM and Wallace DR. (1995) Dopamine D2 and D3 receptors in the rat striatum and nucleus accumbens: use of 7-OH-DPAT and [125I]-iodosulpride. Synapse 19: 1-13 [PMID:7709338]

49. Boulay D, Depoortere R, Oblin A, Sanger DJ, Schoemaker H and Perrault G. (2000) Haloperidol-induced catalepsy is absent in dopamine $D(2)$, but maintained in dopamine $D(3)$ receptor knock-out mice. Eur. J. Pharmacol. 391: 63-73 [PMID:10720636]

50. Boulay D, Depoortere R, Perrault G, Borrelli E and Sanger DJ. (1999) Dopamine $D_{2}$ receptor knock-out mice are insensitive to the hypolocomotor and hypothermic effects of dopamine $D_{2} / D_{3}$ receptor agonists. Neuropharmacology 38: 1389-1396 [PMID:10471093]

51. Boulay D, Depoortere R, Rostene W, Perrault G and Sanger DJ. (1999) Dopamine D3 receptor agonists produce similar decreases in body temperature and locomotor activity in D3 knock-out and wild-type mice. Neuropharmacology 38: 555-65 [PMID:10221759]

52. Bouthenet ML, Souil E, Martres MP, Sokoloff P, Giros B and Schwartz JC. (1991) Localization of dopamine $\mathrm{D} 3$ receptor mRNA in the rat brain using in situ hybridization histochemistry: comparison with dopamine D2 receptor mRNA. Brain Res. 564: 203-19 [PMID:1839781]

53. Bowery B, Rothwell LA and Seabrook GR. (1994) Comparison between the pharmacology of dopamine receptors mediating the inhibition of cell firing in rat brain slices through the substantia nigra pars compacta and ventral tegmental area. Br. J. Pharmacol. 112: 873-80 [PMID:7921615]

54. Boyce-Rustay JM and Risinger FO. (2003) Dopamine D3 receptor knockout mice and the motivational effects of ethanol. Pharmacol. Biochem. Behav. 75: 373-9 [PMID:12873629]

55. Boyfield I, Winn F and Coldwell M. (1996) Comparison of agonist potencies at human dopamine D2 and D3 receptors, expressed in the same cell line, using the Cytosensor Microphysiometer. Biochem Soc Trans 24: 57S-57S [PMID:8674731]

56. Breese GR, Duncan GE, Napier TC, Bondy SC, lorio LC and Mueller RA. (1987) 6-hydroxydopamine treatments enhance behavioral responses to intracerebral microinjection of D1- and D2-dopamine agonists into nucleus accumbens and striatum without changing dopamine antagonist binding. J. Pharmacol. Exp. Ther. 240: 167-76 [PMID:3100767]

57. Brown JH and Makman MH. (1973) Stimulation by dopamine of adenylate cyclase in retinal homogenates and of adenosine-3':5'-cyclic monophosphate formation in intact retina. Proc. Natl. Acad. Sci. U.S.A. 69: 539-543 [PMID:4401122]

58. Bughi S, Jost-Vu E, Antonipillai I, Nadler J and Horton R. (1994) Effect of dopamine2 blockade on renal function under varied sodium intake. J. Clin. Endocrinol. Metab. 78: 1079-84 [PMID:8175964]

59. Bunzow JR, Van Tol HH, Grandy DK, Albert P, Salon J, Christie M, Machida CA, Neve KA and Civelli O. (1988) Cloning and expression of a rat D2 dopamine receptor cDNA. Nature 336: $783-7$ [PMID:2974511]

60. Burris KD, Pacheco MA, Filtz TM, Kung MP, Kung HF and Molinoff PB. (1995) Lack of discrimination by agonists for D2 and D3 dopamine receptors. Neuropsychopharmacology 12: 335-45 [PMID:7576010]

61. Burstein ES, Ma J, Wong S, Gao Y, Pham E, Knapp AE, Nash NR, Olsson R, Davis RE and Hacksell Let al.. (2005) Intrinsic efficacy of antipsychotics at human D2, D3, and D4 dopamine receptors: identification of the clozapine metabolite N-desmethylclozapine as a D2/D3 partial agonist. J. Pharmacol. Exp. Ther. 315: 1278-87 [PMID:16135699]

62. Cabello N, Gandía J, Bertarelli DC, Watanabe M, Lluís C, Franco R, Ferré S, Luján R and Ciruela F. (2009) Metabotropic glutamate type 5, dopamine D2 and adenosine A2a receptors form higher-order oligomers in living cells. J. Neurochem. 109: 1497-507 [PMID:19344374]

63. Cadet JL, Zhu SM and Angulo JA. (1992) Quantitative in situ hybridization evidence for differential 
regulation of proenkephalin and dopamine D2 receptor mRNA levels in the rat striatum: effects of unilateral intrastriatal injections of 6-hydroxydopamine. Brain Res. Mol. Brain Res. 12: 59-67 [PMID:1312206]

64. Cahill E, Pascoli V, Trifilieff P, Savoldi D, Kappès V, Lüscher C, Caboche J and Vanhoutte P. (2014) D1R/GluN1 complexes in the striatum integrate dopamine and glutamate signalling to control synaptic plasticity and cocaine-induced responses. Mol. Psychiatry 19: 1295-304 [PMID:25070539]

65. Caine SB and Koob GF. (1993) Modulation of cocaine self-administration in the rat through D-3 dopamine receptors. Science 260: 1814-6 [PMID:8099761]

66. Caine SB, Negus SS, Mello NK, Patel S, Bristow L, Kulagowski J, Vallone D, Saiardi A and Borrelli E. (2002) Role of dopamine D2-like receptors in cocaine self-administration: studies with D2 receptor mutant mice and novel D2 receptor antagonists. J. Neurosci. 22: 2977-88 [PMID:11923462]

67. Calabresi P, Saiardi A, Pisani A, Baik JH, Centonze D, Mercuri NB, Bernardi G and Borrelli E. (1997) Abnormal synaptic plasticity in the striatum of mice lacking dopamine D2 receptors. J. Neurosci. 17: 453644 [PMID:9169514]

68. Canals M, Marcellino D, Fanelli F, Ciruela F, de Benedetti P, Goldberg SR, Neve K, Fuxe K, Agnati LF and Woods AS et al.. (2003) Adenosine A2A-dopamine D2 receptor-receptor heteromerization: qualitative and quantitative assessment by fluorescence and bioluminescence energy transfer. J. Biol. Chem. 278: 467419 [PMID:12933819]

69. Carey RM, Stote RM, Dubb JW, Townsend LH, Rose Jr CE and Kaiser DL. (1984) Selective peripheral dopamine-1 receptor stimulation with fenoldopam in human essential hypertension. J. Clin. Invest. 74: 2198-207 [PMID:6150942]

70. Carlsson A. (2001) A paradigm shift in brain research.Science 294: 1021-4 [PMID:11691978]

71. CARLSSON A, LINDQVIST M and MAGNUSSON T. (1957) 3,4-Dihydroxyphenylalanine and 5hydroxytryptophan as reserpine antagonists. Nature 180: 1200 [PMID:13483658]

72. Carriba P, Navarro G, Ciruela F, Ferré S, Casadó V, Agnati L, Cortés A, Mallol J, Fuxe K and Canela Eet al.. (2008) Detection of heteromerization of more than two proteins by sequential BRET-FRETNat. Methods 5: 727-33 [PMID:18587404]

73. Carta AR, Gerfen CR and Steiner H. (2000) Cocaine effects on gene regulation in the striatum and behavior: increased sensitivity in D3 dopamine receptor-deficient mice. Neuroreport 11: 2395-9 [PMID:10943692]

74. Castellano MA, Liu LX, Monsma Jr FJ, Sibley DR, Kapatos G and Chiodo LA. (1993) Transfected D2 short dopamine receptors inhibit voltage-dependent potassium current in neuroblastoma $\times$ glioma hybrid (NG108-15) cells. Mol. Pharmacol. 44: 649-56 [PMID:8371717]

75. Castelletti L, Memo M, Missale C, Spano PF and Valerio A. (1989) Potassium channels involved in the transduction mechanism of dopamine D2 receptors in rat lactotrophs. J. Physiol. (Lond.) 410: 251-65 [PMID:2552081]

76. Centonze D, Grande C, Saulle E, Martin AB, Gubellini P, Pavón N, Pisani A, Bernardi G, Moratalla R and Calabresi P. (2003) Distinct roles of D1 and D5 dopamine receptors in motor activity and striatal synaptic plasticity. J. Neurosci. 23: 8506-12 [PMID:13679419]

77. Centonze D, Gubellini P, Usiello A, Rossi S, Tscherter A, Bracci E, Erbs E, Tognazzi N, Bernardi G and Pisani A et al.. (2004) Differential contribution of dopamine D2S and D2L receptors in the modulation of glutamate and GABA transmission in the striatum. Neuroscience 129: 157-66 [PMID:15489038]

78. Cervo L, Burbassi S, Colovic M and Caccia S. (2005) Selective antagonist at D3 receptors, but not nonselective partial agonists, influences the expression of cocaine-induced conditioned place preference in free-feeding rats. Pharmacol. Biochem. Behav. 82: 727-34 [PMID:16405981]

79. Cervo L, Cocco A, Petrella C and Heidbreder CA. (2007) Selective antagonism at dopamine D3 receptors attenuates cocaine-seeking behaviour in the rat. Int. J. Neuropsychopharmacol. 10: 167-81 [PMID:16426478]

80. Chaperon $\mathrm{F}$ and Thiébot MH. (1996) Effects of dopaminergic D3-receptor-preferring ligands on the acquisition of place conditioning in rats. Behav Pharmacol7: 105-109 [PMID:11224401] 
81. Chemel BR, Roth BL, Armbruster B, Watts VJ and Nichols DE. (2006) WAY-100635 is a potent dopamine D4 receptor agonist. Psychopharmacology (Berl.) 188: 244-51 [PMID:16915381]

82. Chen $\mathrm{C}$ and Lokhandwala MF. (1993) Inhibition of $\mathrm{Na}+, \mathrm{K}(+)-A T P a s e$ in rat renal proximal tubules by dopamine involved DA-1 receptor activation. Naunyn Schmiedebergs Arch. Pharmacol. 347: 289-95 [PMID:8097567]

83. Chen K, Deng K, Wang X, Wang Z, Zheng S, Ren H, He D, Han Y, Asico LD and Jose Pßt al.. (2015) Activation of $\mathrm{D} 4$ dopamine receptor decreases angiotensin II type 1 receptor expression in rat renal proximal tubule cells. Hypertension 65: 153-60 [PMID:25368031]

84. Chien EY, Liu W, Zhao Q, Katritch V, Han GW, Hanson MA, Shi L, Newman AH, Javitch JA and Cherezov $\checkmark$ et al.. (2010) Structure of the human dopamine D3 receptor in complex with a D2/D3 selective antagonist. Science 330: 1091-5 [PMID:21097933]

85. Chio CL, Drong RF, Riley DT, Gill GS, Slightom JL and Huff RM. (1994) D4 dopamine receptor-mediated signaling events determined in transfected Chinese hamster ovary cells. J. Biol. Chem. 269: 11813-9 [PMID:7512953]

86. Chio CL, Lajiness ME and Huff RM. (1994) Activation of heterologously expressed D3 dopamine receptors: comparison with D2 dopamine receptors. Mol. Pharmacol. 45: 51-60 [PMID:8302280]

87. Choi JK, Mandeville JB, Chen YI, Grundt P, Sarkar SK, Newman AH and Jenkins BG. (2010) Imaging brain regional and cortical laminar effects of selective D3 agonists and antagonists. Psychopharmacology (Berl.) 212: 59-72 [PMID:20628733]

88. Choi S, Haggart D, Toll L and Cuny GD. (2004) Synthesis, receptor binding and functional studies of mesoridazine stereoisomers. Bioorg. Med. Chem. Lett. 14: 4379-82 [PMID:15357957]

89. Chumpradit S, Kung MP, Vessotskie J, Foulon C, Mu M and Kung HF. (1994) lodinated 2-aminotetralins and 3-amino-1-benzopyrans: ligands for dopamine D2 and D3 receptors. J. Med. Chem. 37: 4245-50 [PMID:7990123]

90. Chun LS, Free RB, Doyle TB, Huang XP, Rankin ML and Sibley DR. (2013) D1-D2 dopamine receptor synergy promotes calcium signaling via multiple mechanisms. Mol. Pharmacol. 84: 190-200 [PMID:23680635]

91. Ciliax BJ, Nash N, Heilman C, Sunahara R, Hartney A, Tiberi M, Rye DB, Caron MG, Niznik HB and Levey Al. (2000) Dopamine D(5) receptor immunolocalization in rat and monkey brain. Synapse 37: 125-45 [PMID:10881034]

92. Civelli O, Bunzow JR and Grandy DK. (1993) Molecular diversity of the dopamine receptors.Annu. Rev. Pharmacol. Toxicol. 33: 281-307 [PMID:8494342]

93. Clemens S, Sawchuk MA and Hochman S. (2005) Reversal of the circadian expression of tyrosinehydroxylase but not nitric oxide synthase levels in the spinal cord of dopamine D3 receptor knockout mice. Neuroscience 133: 353-7 [PMID:15878801]

94. Cohen Al, Todd RD, Harmon S and O'Malley KL. (1992) Photoreceptors of mouse retinas possess D4 receptors coupled to adenylate cyclase. Proc. Natl. Acad. Sci. U.S.A. 89: 12093-7 [PMID:1334557]

95. Collins GT, Butler P, Wayman C, Ratcliffe S, Gupta P, Oberhofer G and Caine SB. (2012) Lack of abuse potential in a highly selective dopamine D3 agonist, PF-592,379, in drug self-administration and drug discrimination in rats. Behav Pharmacol 23: 280-91 [PMID:22470105]

96. Collo G, Bono F, Cavalleri L, Plebani L, Merlo Pich E, Millan MJ, Spano PF and Missale C. (2012) Presynaptic dopamine $D(3)$ receptor mediates cocaine-induced structural plasticity in mesencephalic dopaminergic neurons via ERK and Akt pathways. J. Neurochem. 120: 765-78 [PMID:22145570]

97. Collo G, Bono F, Cavalleri L, Plebani L, Mitola S, Merlo Pich E, Millan MJ, Zoli M, Maskos U and Spano P et al.. (2013) Nicotine-induced structural plasticity in mesencephalic dopaminergic neurons is mediated by dopamine D3 receptors and Akt-mTORC1 signaling. Mol. Pharmacol. 83: 1176-89 [PMID:23543412]

98. Conroy JL, Free RB and Sibley DR. (2015) Identification of G protein-biased agonists that fail to recruit $\beta$ arrestin or promote internalization of the D1 dopamine receptor. ACS Chem Neurosci 6: 681-92 [PMID:25660762]

99. Cook CC and Gurling HM. (1994) The D2 dopamine receptor gene and alcoholism: a genetic effect in the 
liability for alcoholism. $J$ R Soc Med 87: 400-2 [PMID:8046727]

100. Cooper DC, Loeltzow TE, Xu M, Tonegawa S, White FJ and Wolf ME. (1996) Regulations of dopamine release and synthesis in dopamine D3R receptor knockout mice. (Abstract) Soc. Neurosci. Abst. 22: 1319-

101. Corvol JC, Valjent E, Pascoli V, Robin A, Stipanovich A, Luedtke RR, Belluscio L, Girault JA and Hervé D. (2007) Quantitative changes in Galphaolf protein levels, but not D1 receptor, alter specifically acute responses to psychostimulants. Neuropsychopharmacology 32: 1109-21 [PMID:17063155]

102. Cox BA, Rosser MP, Kozlowski MR, Duwe KM, Neve RL and Neve KA. (1995) Regulation and functional characterization of a rat recombinant dopamine D3 receptor. Synapse 21: 1-9 [PMID:8525456]

103. Crocq MA, Mant R, Asherson P, Williams J, Hode Y, Mayerova A, Collier D, Lannfelt L, Sokoloff $P$ and Schwartz JC et al.. (1992) Association between schizophrenia and homozygosity at the dopamine D3 receptor gene. J. Med. Genet. 29: 858-60 [PMID:1362221]

104. Cunningham CL, Howard MA, Gill SJ, Rubinstein M, Low MJ and Grandy DK. (2000) Ethanol-conditioned place preference is reduced in dopamine D2 receptor-deficient mice. Pharmacol. Biochem. Behav. 67: 693-9 [PMID:11166059]

105. Daly SA and Waddington JL. (1993) Behavioural effects of the putative D-3 dopamine receptor agonist 7OH-DPAT in relation to other "D-2-like" agonists. Neuropharmacology 32: 509-10 [PMID:8321432]

106. Damsma G, Bottema T, Westerink BH, Tepper PG, Dijkstra D, Pugsley TA, MacKenzie RG, Heffner TG and Wikström H. (1993) Pharmacological aspects of R-(+)-7-OH-DPAT, a putative dopamine D3 receptor ligand. Eur. J. Pharmacol. 249: R9-10 [PMID:8287911]

107. Darmopil S, Martín AB, De Diego IR, Ares S and Moratalla R. (2009) Genetic inactivation of dopamine D1 but not D2 receptors inhibits L-DOPA-induced dyskinesia and histone activation. Biol. Psychiatry 66: 60313 [PMID:19520364]

108. Dearry A, Gingrich JA, Falardeau P, Fremeau Jr RT, Bates MD and Caron MG. (1990) Molecular cloning and expression of the gene for a human D1 dopamine receptor. Nature 347: 72-6 [PMID:2144334]

109. Depoortere R, Perrault $G$ and Sanger DJ. (1996) Behavioural effects in the rat of the putative dopamine D3 receptor agonist 7-OH-DPAT: comparison with quinpirole and apomorphine. Psychopharmacology (Berl.) 124: 231-40 [PMID:8740044]

110. Devoto P, Collu M, Muntoni AL, Pistis M, Serra G, Gessa GL and Diana M. (1995) Biochemical and electrophysiological effects of 7-OH-DPAT on the mesolimbic dopaminergic system. Synapse 20: 153-5 [PMID:7570345]

111. Diaz J, Lévesque D, Lammers CH, Griffon N, Martres MP, Schwartz JC and Sokoloff P. (1995) Phenotypical characterization of neurons expressing the dopamine D3 receptor in the rat brain. Neuroscience 65: 731-45 [PMID:7609872]

112. Diaz J, Pilon C, Le Foll B, Gros C, Triller A, Schwartz JC and Sokoloff P. (2000) Dopamine D3 receptors expressed by all mesencephalic dopamine neurons. J. Neurosci. 20: 8677-84 [PMID:11102473]

113. Dickinson SD, Sabeti J, Larson GA, Giardina K, Rubinstein M, Kelly MA, Grandy DK, Low MJ, Gerhardt GA and Zahniser NR. (1999) Dopamine D2 receptor-deficient mice exhibit decreased dopamine transporter function but no changes in dopamine release in dorsal striatum. J. Neurochem. 72: 148-56 [PMID:9886065]

114. Dijkstra D, Rodenhuis N, Vermeulen ES, Pugsley TA, Wise LD and Wikström HV. (2002) Further characterization of structural requirements for ligands at the dopamine $\mathrm{D}(2)$ and $\mathrm{D}(3)$ receptor: exploring the thiophene moiety. J. Med. Chem. 45: 3022-31 [PMID:12086487]

115. Drago J, Gerfen CR, Lachowicz JE, Steiner H, Hollon TR, Love PE, Ooi GT, Grinberg A, Lee EJ and Huang SP et al.. (1994) Altered striatal function in a mutant mouse lacking D1A dopamine receptors.Proc. Natl. Acad. Sci. U.S.A. 91: 12564-8 [PMID:7809078]

116. Dulawa SC, Grandy DK, Low MJ, Paulus MP and Geyer MA. (1999) Dopamine D4 receptor-knock-out mice exhibit reduced exploration of novel stimuli. J. Neurosci. 19: 9550-6 [PMID:10531457]

117. Durcan MJ, Rigdon GC, Norman MH and Morgan PF. (1995) Is clozapine selective for the dopamine D4 receptor? Life Sci. 57: PL275-83 [PMID:7475902]

118. El-Faddagh M, Laucht M, Maras A, Vöhringer L and Schmidt MH. (2004) Association of dopamine D4 
receptor (DRD4) gene with attention-deficit/hyperactivity disorder (ADHD) in a high-risk community sample: a longitudinal study from birth to 11 years of age. J Neural Transm (Vienna) 111: 883-9 [PMID:15206004]

119. El-Ghundi M, Fletcher PJ, Drago J, Sibley DR, O'Dowd BF and George SR. (1999) Spatial learning deficit in dopamine $\mathrm{D}(1)$ receptor knockout mice. Eur. J. Pharmacol. 383: 95-106 [PMID:10585522]

120. El-Ghundi M, George SR, Drago J, Fletcher PJ, Fan T, Nguyen T, Liu C, Sibley DR, Westphal H and O'Dowd BF. (1998) Disruption of dopamine D1 receptor gene expression attenuates alcohol-seeking behavior. Eur. J. Pharmacol. 353: 149-58 [PMID:9726645]

121. El-Ghundi M, O'Dowd BF, Erclik M and George SR. (2003) Attenuation of sucrose reinforcement in dopamine D1 receptor deficient mice. Eur. J. Neurosci. 17: 851-62 [PMID:12603275]

122. El-Ghundi M, O'Dowd BF and George SR. (2001) Prolonged fear responses in mice lacking dopamine D1 receptor. Brain Res. 892: 86-93 [PMID:11172752]

123. Elmer Gl, Pieper JO, Levy J, Rubinstein M, Low MJ, Grandy DK and Wise RA. (2005) Brain stimulation and morphine reward deficits in dopamine D2 receptor-deficient mice. Psychopharmacology (Berl.) 182: 33-44 [PMID:16136297]

124. Emamian ES, Hall D, Birnbaum MJ, Karayiorgou M and Gogos JA. (2004) Convergent evidence for impaired AKT1-GSK3beta signaling in schizophrenia. Nat. Genet. 36: 131-7 [PMID:14745448]

125. Espinoza S, Masri B, Salahpour A and Gainetdinov RR. (2013) BRET approaches to characterize dopamine and TAAR1 receptor pharmacology and signaling. Methods Mol. Biol. 964: 107-22 [PMID:23296781]

126. Espinoza S, Salahpour A, Masri B, Sotnikova TD, Messa M, Barak LS, Caron MG and Gainetdinov RR. (2011) Functional interaction between trace amine-associated receptor 1 and dopamine D2 receptor. Mol. Pharmacol. 80: 416-25 [PMID:21670104]

127. Falzone TL, Gelman DM, Young JI, Grandy DK, Low MJ and Rubinstein M. (2002) Absence of dopamine D4 receptors results in enhanced reactivity to unconditioned, but not conditioned, fear. Eur. J. Neurosci. 15: 158-64 [PMID:11860516]

128. Fasano S, Bezard E, D'Antoni A, Francardo V, Indrigo M, Qin L, Doveró S, Cerovic M, Cenci MA and Brambilla R. (2010) Inhibition of Ras-guanine nucleotide-releasing factor 1 (Ras-GRF1) signaling in the striatum reverts motor symptoms associated with L-dopa-induced dyskinesia. Proc. Natl. Acad. Sci. U.S.A. 107: 21824-9 [PMID:21115823]

129. Ferré S, Baler R, Bouvier M, Caron MG, Devi LA, Durroux T, Fuxe K, George SR, Javitch JA and Lohse MJ et al.. (2009) Building a new conceptual framework for receptor heteromers.Nat. Chem. Biol. 5: 131-4 [PMID:19219011]

130. Fiorentini C, Busi C, Gorruso E, Gotti C, Spano P and Missale C. (2008) Reciprocal regulation of dopamine D1 and D3 receptor function and trafficking by heterodimerization. Mol. Pharmacol. 74: 59-69 [PMID:18424554]

131. Fiorentini C, Gardoni F, Spano P, Di Luca M and Missale C. (2003) Regulation of dopamine D1 receptor trafficking and desensitization by oligomerization with glutamate $\mathrm{N}$-methyl-D-aspartate receptors. J. Biol. Chem. 278: 20196-202 [PMID:12646556]

132. Fiorentini C, Mattanza C, Collo G, Savoia P, Spano P and Missale C. (2011) The tyrosine phosphatase Shp-2 interacts with the dopamine $D(1)$ receptor and triggers $D(1)$-mediated Erk signaling in striatal neurons. J. Neurochem. 117: 253-63 [PMID:21272002]

133. Fiorentini C, Savoia P, Savoldi D, Barbon A and Missale C. (2013) Persistent activation of the D1R/Shp2/Erk1/2 pathway in I-DOPA-induced dyskinesia in the 6-hydroxy-dopamine rat model of Parkinson's disease. Neurobiol. Dis. 54: 339-48 [PMID:23328768]

134. Fishburn CS, Belleli D, David C, Carmon S and Fuchs S. (1993) A novel short isoform of the D3 dopamine receptor generated by alternative splicing in the third cytoplasmic loop. J. Biol. Chem. 268: 5872-8 [PMID:8449953]

135. Fishburn CS, Carmon S and Fuchs S. (1995) Molecular cloning and characterisation of the gene encoding the murine $\mathrm{D}_{4}$ dopamine receptor. FEBS Lett. 361: 215-219 [PMID:7698326] 
136. Flores-Hernández J, Cepeda C, Hernández-Echeagaray E, Calvert CR, Jokel ES, Fienberg AA, Greengard P and Levine MS. (2002) Dopamine enhancement of NMDA currents in dissociated mediumsized striatal neurons: role of D1 receptors and DARPP-32. J. Neurophysiol. 88: 3010-20 [PMID:12466426]

137. Fowler SC, Zarcone TJ, Vorontsova E and Chen R. (2002) Motor and associative deficits in D2 dopamine receptor knockout mice. Int. J. Dev. Neurosci. 20: 309-21 [PMID:12175868]

138. Frederick AL, Yano $H$, Trifilieff $P$, Vishwasrao HD, Biezonski D, Mészáros J, Urizar E, Sibley DR, Kellendonk $C$ and Sonntag KC et al.. (2015) Evidence against dopamine D1/D2 receptor heteromers.Mol. Psychiatry 20: 1373-85 [PMID:25560761]

139. Free RB, Chun LS, Moritz AE, Miller BN, Doyle TB, Conroy JL, Padron A, Meade JA, Xiao J and Hu Xet al.. (2014) Discovery and characterization of a $G$ protein-biased agonist that inhibits $\beta$-arrestin recruitment to the D2 dopamine receptor. Mol. Pharmacol. 86: 96-105 [PMID:24755247]

140. Freedman SB, Patel S, Marwood R, Emms F, Seabrook GR, Knowles MR and McAllister G. (1994) Expression and pharmacological characterization of the human D3 dopamine receptor. J. Pharmacol. Exp. Ther. 268: 417-26 [PMID:8301582]

141. Furman CA, Roof RA, Moritz AE, Miller BN, Doyle TB, Free RB, Banala AK, Paul NM, Kumar V and Sibley $\mathrm{CD}$ et al.. (2015) Investigation of the binding and functional properties of extended length D3 dopamine receptor-selective antagonists. Eur Neuropsychopharmacol 25: 1448-61 [PMID:25583363]

142. Fuxe K, Marcellino D, Guidolin D, Woods AS and Agnati LF. (2008) Heterodimers and receptor mosaics of different types of G-protein-coupled receptors. Physiology (Bethesda) 23: 322-32 [PMID:19074740]

143. Gainetdinov RR, Sotnikova TD, Grekhova TV and Rayevsky KS. (1996) In vivo evidence for preferential role of dopamine D3 receptor in the presynaptic regulation of dopamine release but not synthesis. Eur. J. Pharmacol. 308: 261-9 [PMID:8858296]

144. Galaj E, Ananthan S, Saliba M and Ranaldi R. (2014) The effects of the novel DA D3 receptor antagonist SR 21502 on cocaine reward, cocaine seeking and cocaine-induced locomotor activity in rats. Psychopharmacology (Berl.) 231: 501-10 [PMID:24037509]

145. Gandelman KY, Harmon S, Todd RD and O'Malley KL. (1991) Analysis of the structure and expression of the human dopamine D2A receptor gene. J. Neurochem. 56: 1024-9 [PMID:1825222]

146. Gazi L, Bobirnac I, Danzeisen M, Schüpbach E, Bruinvels AT, Geisse S, Sommer B, Hoyer D, Tricklebank $M$ and Schoeffter P. (1998) The agonist activities of the putative antipsychotic agents, L-745,870 and U101958 in HEK293 cells expressing the human dopamine D4.4 receptor. Br. J. Pharmacol. 124: 889-96 [PMID:9692773]

147. Gazi L, Bobirnac I, Danzeisen M, Schüpbach E, Langenegger D, Sommer B, Hoyer D, Tricklebank M and Schoeffter P. (1999) Receptor density as a factor governing the efficacy of the dopamine D4 receptor ligands, L-745,870 and U-101958 at human recombinant D4.4 receptors expressed in $\mathrm{CHO}$ cells. Br. J. Pharmacol. 128: 613-20 [PMID:10516640]

148. Gazi L, Schoeffter P, Nunn C, Croskery K, Hoyer D and Feuerbach D. (2000) Cloning, expression, functional coupling and pharmacological characterization of the rat dopamine D4 receptor. Naunyn Schmiedebergs Arch. Pharmacol. 361: 555-64 [PMID:10832611]

149. Gehlert DR, Gackenheimer SL, Seeman P and Schaus J. (1992) Autoradiographic localization of [3H]quinpirole binding to dopamine D2 and D3 receptors in rat brain. Eur. J. Pharmacol. 211: 189-94 [PMID:1351846]

150. George M, Amrutheshwar R, Rajkumar RP, Kattimani S and Dkhar SA. (2013) Newer antipsychotics and upcoming molecules for schizophrenia. Eur. J. Clin. Pharmacol. 69: 1497-509 [PMID:23545936]

151. Gilbert DB and Cooper SJ. (1995) 7-OH-DPAT injected into the accumbens reduces locomotion and sucrose ingestion: D3 autoreceptor-mediated effects? Pharmacol. Biochem. Behav. 52: 275-80 [PMID:8577791]

152. Gilbert JG, Newman AH, Gardner EL, Ashby Jr CR, Heidbreder CA, Pak AC, Peng XQ and Xi ZX. (2005) Acute administration of SB-277011A, NGB 2904, or BP 897 inhibits cocaine cue-induced reinstatement of drug-seeking behavior in rats: role of dopamine D3 receptors. Synapse 57: 17-28 [PMID:15858839]

153. Gill RS, Hsiung MS, Sum CS, Lavine N, Clark SD and Van Tol HH. (2010) The dopamine D4 receptor 
activates intracellular platelet-derived growth factor receptor beta to stimulate ERK1/2. Cell. Signal. 22: 285-90 [PMID:19782129]

154. Ginés S, Hillion J, Torvinen M, Le Crom S, Casadó V, Canela El, Rondin S, Lew JY, Watson S and Zoli M et al.. (2000) Dopamine D1 and adenosine A1 receptors form functionally interacting heteromeric complexes. Proc. Natl. Acad. Sci. U.S.A. 97: 8606-11 [PMID:10890919]

155. Girault JA. (2012) Signaling in striatal neurons: the phosphoproteins of reward, addiction, and dyskinesia. Prog Mol Biol Transl Sci 106: 33-62 [PMID:22340713]

156. Giros B, Martres M-P, Sokoloff $P$ and Schwartz J-C. (1990) cDNA cloning of the human dopaminergic $B_{3}$ receptor and chromosome identification. C. R. Acad. Sci. III311: 501-508 [PMID:2129115]

157. Giros B, Martres MP, Pilon C, Sokoloff P and Schwartz JC. (1991) Shorter variants of the B dopamine receptor produced through various patterns of alternative splicing. Biochem. Biophys. Res. Commun. 176: 1584-1592 [PMID:2039532]

158. Giros B, Sokoloff P, Martres MP, Riou JF, Emorine LJ and Schwartz JC. (1989) Alternative splicing directs the expression of two D2 dopamine receptor isoforms. Nature 342: 923-6 [PMID:2531847]

159. Glavin GB and Hall AM. (1994) Clozapine, a dopamine DA4 receptor antagonist, reduces gastric acid secretion and stress-induced gastric mucosal injury. Life Sci. 54: PL261-4 [PMID:8152334]

160. Gobert A, Rivet JM, Audinot V, Cistarelli L, Spedding M, Vian J, Peglion JL and Millan MJ. (1995) Functional correlates of dopamine D3 receptor activation in the rat in vivo and their modulation by the selective antagonist, (+)-S 14297: II. Both D2 and "silent" D3 autoreceptors control synthesis and release in mesolimbic, mesocortical and nigrostriatal pathways. J. Pharmacol. Exp. Ther. 275: 899-913 [PMID:7473181]

161. Grady DL, Thanos PK, Corrada MM, Barnett Jr JC, Ciobanu V, Shustarovich D, Napoli A, Moyzis AG, Grandy D and Rubinstein M et al.. (2013) DRD4 genotype predicts longevity in mouse and human.J. Neurosci. 33: 286-91 [PMID:23283341]

162. Grandy DK, Marchionni MA, Makam H, Stofko RE, Alfano M, Frothingham L, Fischer JB, Burke-Howie KJ, Bunzow JR and Server AC et al.. (1989) Cloning of the cDNA and gene for a human D2 dopamine receptor. Proc. Natl. Acad. Sci. U.S.A. 86: 9762-6 [PMID:2532362]

163. Grandy DK, Zhang YA, Bouvier C, Zhou QY, Johnson RA, Allen L, Buck K, Bunzow JR, Salon J and Civelli O. (1991) Multiple human D5 dopamine receptor genes: a functional receptor and two pseudogenes. Proc. Natl. Acad. Sci. U.S.A. 88: 9175-9 [PMID:1833775]

164. Graziane NM, Yuen EY and Yan Z. (2009) Dopamine D4 Receptors Regulate GABAA Receptor Trafficking via an Actin/Cofilin/Myosin-dependent Mechanism. J. Biol. Chem. 284: 8329-36 [PMID:19179335]

165. Gregori-Puigjané E, Setola V, Hert J, Crews BA, Irwin JJ, Lounkine E, Marnett L, Roth BL and Shoichet BK. (2012) Identifying mechanism-of-action targets for drugs and probes. Proc. Natl. Acad. Sci. U.S.A. 109: 11178-83 [PMID:22711801]

166. Griffon N, Crocq MA, Pilon C, Martres MP, Mayerova A, Uyanik G, Burgert E, Duval F, Macher JP and Javoy-Agid F et al.. (1996) Dopamine D3 receptor gene: organization, transcript variants, and polymorphism associated with schizophrenia. Am. J. Med. Genet. 67: 63-70 [PMID:8678117]

167. Grundt P, Husband SL, Luedtke RR, Taylor M and Newman AH. (2007) Analogues of the dopamine D2 receptor antagonist L741,626: Binding, function, and SAR. Bioorg. Med. Chem. Lett. 17: 745-9 [PMID:17095222]

168. Grundt P, Prevatt KM, Cao J, Taylor M, Floresca CZ, Choi JK, Jenkins BG, Luedtke RR and Newman AH. (2007) Heterocyclic analogues of N-(4-(4-(2,3-dichlorophenyl)piperazin-1-yl)butyl)arylcarboxamides with functionalized linking chains as novel dopamine D3 receptor ligands: potential substance abuse therapeutic agents. J. Med. Chem. 50: 4135-46 [PMID:17672446]

169. Guiramand J, Montmayeur JP, Ceraline J, Bhatia M and Borrelli E. (1995) Alternative splicing of the dopamine D2 receptor directs specificity of coupling to G-proteins. J Biol Chem 270: 7354-7358 [PMID:7706278]

170. Guitart X, Navarro G, Moreno E, Yano H, Cai NS, Sánchez-Soto M, Kumar-Barodia S, Naidu YT, Mallol J and Cortés A et al.. (2014) Functional selectivity of allosteric interactions within $G$ protein-coupled receptor 
oligomers: the dopamine D1-D3 receptor heterotetramer. Mol. Pharmacol. 86: 417-29 [PMID:25097189]

171. Hachimine P, Seepersad N, Ananthan S and Ranaldi R. (2014) The novel dopamine D3 receptor antagonist, SR 21502, reduces cocaine conditioned place preference in rats. Neurosci. Lett. 569: 137-41 [PMID:24704326]

172. Han X, Li B, Ye X, Mulatibieke T, Wu J, Dai J, Wu D, Ni J, Zhang R and Xue $\notin t$ al.. (2017) Dopamine $D_{2}$ receptor signalling controls inflammation in acute pancreatitis via a PP2A-dependent Akt/NF-kB signalling pathway. Br. J. Pharmacol. 174: 4751-4770 [PMID:28963856]

173. Hasbi A, Fan T, Alijaniaram M, Nguyen T, Perreault ML, O'Dowd BF and George SR. (2009) Calcium signaling cascade links dopamine D1-D2 receptor heteromer to striatal BDNF production and neuronal growth. Proc. Natl. Acad. Sci. U.S.A. 106: 21377-82 [PMID:19948956]

174. Hazelwood LA, Free RB, Cabrera DM, Skinbjerg M and Sibley DR. (2008) Reciprocal modulation of function between the D1 and D2 dopamine receptors and the Na+,K+-ATPase. J. Biol. Chem. 283: 3644153 [PMID:18984584]

175. Heier RF, Dolak LA, Duncan JN, Hyslop DK, Lipton MF, Martin IJ, Mauragis MA, Piercey MF, Nichols NF and Schreur PJ et al.. (1997) Synthesis and biological activities of (R)-5,6-dihydro-N,N-dimethyl-4Himidazo[4,5,1-ij]quinolin-5-amine and its metabolites. J. Med. Chem. 40: 639-46 [PMID:9057850]

176. Heiman M, Schaefer A, Gong S, Peterson JD, Day M, Ramsey KE, Suárez-Fariñas M, Schwarz C, Stephan DA and Surmeier DJ et al.. (2008) A translational profiling approach for the molecular characterization of CNS cell types. Cell 135: 738-48 [PMID:19013281]

177. Heinrich T, Böttcher H, Gericke R, Bartoszyk GD, Anzali S, Seyfried CA, Greiner HE and Van Amsterdam C. (2004) Synthesis and structure--activity relationship in a class of indolebutylpiperazines as dual 5HT(1A) receptor agonists and serotonin reuptake inhibitors. J. Med. Chem. 47: 4684-92 [PMID:15341484]

178. Hernandez-Lopez S, Tkatch T, Perez-Garci E, Galarraga E, Bargas J, Hamm H and Surmeier DJ. (2000) D2 dopamine receptors in striatal medium spiny neurons reduce L-type Ca2+ currents and excitability via a novel PLC[beta]1-IP3-calcineurin-signaling cascade. J. Neurosci. 20: 8987-95 [PMID:11124974]

179. Herroelen L, De Backer JP, Wilczak N, Flamez A, Vauquelin G and De Keyser J. (1994) Autoradiographic distribution of D3-type dopamine receptors in human brain using [3H]7-hydroxy-N,N-di-n-propyl-2aminotetralin. Brain Res. 648: 222-8 [PMID:7922537]

180. Hersi Al, Kitaichi K, Srivastava LK, Gaudreau P and Quirion R. (2000) Dopamine D-5 receptor modulates hippocampal acetylcholine release. Brain Res. Mol. Brain Res. 76: 336-40 [PMID:10762709]

181. Hidaka K, Matsumoto M, Tada S, Tasaki Y and Yamaguchi T. (1995) Differential effects of $[3 \mathrm{H}]$ nemonapride and [3H]spiperone binding on human dopamine D4 receptors. Neurosci. Lett. 186: 145-8 [PMID:7777184]

182. Hillion J, Canals M, Torvinen M, Casado V, Scott R, Terasmaa A, Hansson A, Watson S, Olah ME and Mallol J et al.. (2002) Coaggregation, cointernalization, and codesensitization of adenosine A2A receptors and dopamine D2 receptors. J. Biol. Chem. 277: 18091-7 [PMID:11872740]

183. Himmler A, Stratowa C and Czernilofsky AP. (1993) Functional testing of human dopamine D1 and D5 receptors expressed in stable cAMP-responsive luciferase reporter cell lines. J. Recept. Res. 13: 79-94 [PMID:8383768]

184. Hoare SR, Coldwell MC, Armstrong D and Strange PG. (2000) Regulation of human D(1), d(2(long)), $\mathrm{d}(2$ (short)), $\mathrm{D}(3)$ and $\mathrm{D}(4)$ dopamine receptors by amiloride and amiloride analogues. Br. J. Pharmacol. 130: 1045-59 [PMID:10882389]

185. Hollon TR, Bek MJ, Lachowicz JE, Ariano MA, Mezey E, Ramachandran R, Wersinger SR, Soares-daSilva P, Liu ZF and Grinberg A et al.. (2002) Mice lacking D5 dopamine receptors have increased sympathetic tone and are hypertensive. J. Neurosci. 22: 10801-10 [PMID:12486173]

186. Holmes A, Hollon TR, Gleason TC, Liu Z, Dreiling J, Sibley DR and Crawley JN. (2001) Behavioral characterization of dopamine D5 receptor null mutant mice. Behav. Neurosci. 115: 1129-44 [PMID:11584926]

187. Hu R, Song R, Yang R, Su R and Li J. (2013) The dopamine Bg receptor antagonist YQA14 that inhibits the expression and drug-primed reactivation of morphine-induced conditioned place preference in rats. 


\section{Eur. J. Pharmacol. [PMID:24513519]}

188. Hurd YL, Suzuki M and Sedvall GC. (2001) D1 and D2 dopamine receptor mRNA expression in whole hemisphere sections of the human brain. J. Chem. Neuroanat. 22: 127-37 [PMID:11470560]

189. Hyun JS, Baig MR, Yang DY, Leungwattanakij S, Kim KD, Abdel-Mageed AB, Bivalacqua TJ and Hellstrom WJ. (2002) Localization of peripheral dopamine D1 and D2 receptors in rat and human seminal vesicles. J. Androl. 23: 114-20 [PMID:11783439]

190. laccarino C, Samad TA, Mathis C, Kercret H, Picetti R and Borrelli E. (2002) Control of lactotrop proliferation by dopamine: essential role of signaling through D2 receptors and ERKs. Proc. Natl. Acad. Sci. U.S.A. 99: 14530-5 [PMID:12391292]

191. Ishibashi T, Horisawa T, Tokuda K, Ishiyama T, Ogasa M, Tagashira R, Matsumoto K, Nishikawa H, Ueda $Y$ and Toma $S$ et al.. (2010) Pharmacological profile of lurasidone, a novel antipsychotic agent with potent 5-hydroxytryptamine 7 (5-HT7) and 5-HT1A receptor activity. J. Pharmacol. Exp. Ther. 334: 171-81 [PMID:20404009]

192. Iwakura Y, Nawa H, Sora I and Chao MV. (2008) Dopamine D1 receptor-induced signaling through TrkB receptors in striatal neurons. J. Biol. Chem. 283: 15799-806 [PMID:18381284]

193. Jeanneteau F, Funalot B, Jankovic J, Deng H, Lagarde JP, Lucotte G and Sokoloff P. (2006) A functional variant of the dopamine $\mathrm{D} 3$ receptor is associated with risk and age-at-onset of essential tremor. Proc. Natl. Acad. Sci. U.S.A. 103: 10753-8 [PMID:16809426]

194. Jiang M, Spicher K, Boulay G, Wang Y and Birnbaumer L. (2001) Most central nervous system D2 dopamine receptors are coupled to their effectors by Go. Proc. Natl. Acad. Sci. U.S.A. 98: 3577-82 [PMID:11248120]

195. Joseph JD, Wang YM, Miles PR, Budygin EA, Picetti R, Gainetdinov RR, Caron MG and Wightman RM. (2002) Dopamine autoreceptor regulation of release and uptake in mouse brain slices in the absence of D(3) receptors. Neuroscience 112: 39-49 [PMID:12044470]

196. Kagaya T, Yonaga M, Furuya Y, Hashimoto T, Kuroki J and Nishizawa Y. (1996) Dopamine D3 agonists disrupt social behavior in rats. Brain Res. 721: 229-32 [PMID:8793104]

197. Kanba S, Suzuki E, Nomura S, Nakaki T, Yagi G, Asai M and Richelson E. (1994) Affinity of neuroleptics for D1 receptor of human brain striatum. J Psychiatry Neurosci 19: 265-9 [PMID:7918347]

198. Kebabian JW and Calne DB. (1979) Multiple receptors for dopamine. Nature 277: 93-6 [PMID:215920]

199. Kelly MA, Rubinstein M, Asa SL, Zhang G, Saez C, Bunzow JR, Allen RG, Hnasko R, Ben-Jonathan N, Grandy DK and Low MJ. (1997) Pituitary lactotroph hyperplasia and chronic hyperprolactinemia in dopamine $D_{2}$ receptor-deficient mice. Neuron 19: 103-113 [PMID:9247267]

200. Kelly MA, Rubinstein M, Phillips TJ, Lessov CN, Burkhart-Kasch S, Zhang G, Bunzow J R, Fang Y, Gerhardt GA, Grandy DK and Low MJ. (1998) Locomotor activity in $\mathrm{D}_{2}$ dopamine receptor-deficient mice is determined by gene dosage, genetic background, and developmental adaptations. J. Neurosci. 18: 34703479 [PMID:9547254]

201. Kennedy JL, Billett EA, Macciardi FM, Verga M, Parsons TJ, Meltzer HY, Lieberman J and Buchanan JA. (1995) Association study of dopamine D3 receptor gene and schizophrenia. Am. J. Med. Genet. 60: 55862 [PMID:8825896]

202. Khan ZU, Gutiérrez A, Martín R, Peñafiel A, Rivera A and de la Calle A. (2000) Dopamine D5 receptors of rat and human brain. Neuroscience 100: 689-99 [PMID:11036203]

203. Khroyan TV, Baker DA and Neisewander JL. (1995) Dose-dependent effects of the D3-preferring agonist 7-OH-DPAT on motor behaviors and place conditioning. Psychopharmacology (Berl.) 122: 351-7 [PMID:8657832]

204. Kim DJ, Park BL, Yoon S, Lee HK, Joe KH, Cheon YH, Gwon DH, Cho SN, Lee HW and NamGung Set al.. (2007) 5' UTR polymorphism of dopamine receptor D1 (DRD1) associated with severity and temperament of alcoholism. Biochem. Biophys. Res. Commun. 357: 1135-41 [PMID:17466946]

205. Kim JS, Bailey MJ, Weller JL, Sugden D, Rath MF, Møller M and Klein DC. (2010) Thyroid hormone and adrenergic signaling interact to control pineal expression of the dopamine receptor D4 gene (Drd4). Mol. Cell. Endocrinol. 314: 128-35 [PMID:19482058] 
206. Kisilevsky AE, Mulligan SJ, Altier C, Iftinca MC, Varela D, Tai C, Chen L, Hameed S, Hamid J and Macvicar BA et al.. (2008) D1 receptors physically interact with $\mathrm{N}$-type calcium channels to regulate channel distribution and dendritic calcium entry. Neuron 58: 557-70 [PMID:18498737]

207. Kita JM, Parker LE, Phillips PE, Garris PA and Wightman RM. (2007) Paradoxical modulation of short-term facilitation of dopamine release by dopamine autoreceptors. J. Neurochem. 102: 1115-24 [PMID:17663751]

208. Kling-Petersen T, Ljung E and Svensson K. (1994) The preferential dopamine autoreceptor antagonist (+)UH232 antagonizes the positive reinforcing effects of cocaine and d-amphetamine in the ICSS paradigm. Pharmacol. Biochem. Behav. 49: 345-51 [PMID:7824548]

209. Kling-Petersen T, Ljung E and Svensson K. (1995) Effects on locomotor activity after local application of D3 preferring compounds in discrete areas of the rat brain. J. Neural Transm. Gen. Sect. 102: 209-20 [PMID:8788069]

210. Koeltzow T, Cooper DC, Hu X-T, Xu M, Tonegawa S and White FJ. (1995) In vivo effects of dopaminergic ligands on dopamine D3 receptor deficient mice. (Abstract) Soc. Neurosci. Abst. 21: 364-

211. Kongsamut S, Kang J, Chen XL, Roehr J and Rampe D. (2002) A comparison of the receptor binding and HERG channel affinities for a series of antipsychotic drugs. Eur. J. Pharmacol. 450: 37-41 [PMID:12176106]

212. Kortagere S, Gmeiner P, Weinstein H and Schetz JA. (2004) Certain 1,4-disubstituted aromatic piperidines and piperazines with extreme selectivity for the dopamine D4 receptor interact with a common receptor microdomain. Mol. Pharmacol. 66: 1491-9 [PMID:15448188]

213. Kreiss DS, Bergstrom DA, Gonzalez AM, Huang KX, Sibley DR and Walters JR. (1995) Dopamine receptor agonist potencies for inhibition of cell firing correlate with dopamine D3 receptor binding affinities. Eur J Pharmaco/277: 209-214 [PMID:7493610]

214. Kroeze WK, Hufeisen SJ, Popadak BA, Renock SM, Steinberg S, Ernsberger P, Jayathilake K, Meltzer HY and Roth BL. (2003) H1-histamine receptor affinity predicts short-term weight gain for typical and atypical antipsychotic drugs. Neuropsychopharmacology 28: 519-26 [PMID:12629531]

215. Kroeze WK, Sassano MF, Huang XP, Lansu K, McCorvy JD, Giguère PM, Sciaky N and Roth BL. (2015) PRESTO-Tango as an open-source resource for interrogation of the druggable human GPCRome. Nat. Struct. Mol. Biol. 22: 362-9 [PMID:25895059]

216. Kukreti R, Tripathi $S$, Bhatnagar $P$, Gupta $S$, Chauhan $C$, Kubendran S, Janardhan Reddy YC, Jain $S$ and Brahmachari SK. (2006) Association of DRD2 gene variant with schizophrenia. Neurosci. Lett. 392: 68-71 [PMID:16183199]

217. Kulagowski JJ, Broughton HB, Curtis NR, Mawer IM, Ridgill MP, Baker R, Emms F, Freedman SB, Marwood R and Patel S et al.. (1996) 3-((4-(4-Chlorophenyl)piperazin-1-yl)-methyl)-1H-pyrrolo-2,3-bpyridine: an antagonist with high affinity and selectivity for the human dopamine D4 receptor. J. Med. Chem. 39: 1941-2 [PMID:8642550]

218. Kurashima M, Yamada K, Nagashima M, Shirakawa K and Furukawa T. (1995) Effects of putative dopamine D3 receptor agonists, 7-OH-DPAT, and quinpirole, on yawning, stereotypy, and body temperature in rats. Pharmacol. Biochem. Behav. 52: 503-8 [PMID:8545466]

219. Köhler C, Hall H, Ogren SO and Gawell L. (1985) Specific in vitro and in vivo binding of $3 \mathrm{H}$-raclopride. A potent substituted benzamide drug with high affinity for dopamine D-2 receptors in the rat brain. Biochem. Pharmacol. 34: 2251-9 [PMID:4015674]

220. L'hirondel M, Chéramy A, Godeheu G, Artaud F, Saiardi A, Borrelli E and Glowinski J. (1998) Lack of autoreceptor-mediated inhibitory control of dopamine release in striatal synaptosomes of D2 receptordeficient mice. Brain Res. 792: 253-62 [PMID:9593923]

221. Lacroix LP, Ceolin L, Zocchi A, Varnier G, Garzotti M, Curcuruto O and Heidbreder CA. (2006) Selective dopamine D3 receptor antagonists enhance cortical acetylcholine levels measured with high-performance liquid chromatography/tandem mass spectrometry without anti-cholinesterases. J. Neurosci. Methods 157: 25-31 [PMID:16697046]

222. Lacroix LP, Hows ME, Shah AJ, Hagan JJ and Heidbreder CA. (2003) Selective antagonism at dopamine 
D3 receptors enhances monoaminergic and cholinergic neurotransmission in the rat anterior cingulate cortex. Neuropsychopharmacology 28: 839-49 [PMID:12637956]

223. Lahti RA, Evans DL, Stratman NC and Figur LM. (1993) Dopamine D4 versus D2 receptor selectivity of dopamine receptor antagonists: possible therapeutic implications. Eur. J. Pharmacol. 236: 483-6 [PMID:8102973]

224. Lahti RA, Roberts RC and Tamminga CA. (1995) D2-family receptor distribution in human postmortem tissue: an autoradiographic study. Neuroreport 6: 2505-12 [PMID:8741751]

225. Lajiness ME, Chio CL and Huff RM. (1993) D2 dopamine receptor stimulation of mitogenesis in transfected Chinese hamster ovary cells: relationship to dopamine stimulation of tyrosine phosphorylations. J. Pharmacol. Exp. Ther. 267: 1573-81 [PMID:7903393]

226. Lanau F, Zenner MT, Civelli O and Hartman DS. (1997) Epinephrine and norepinephrine act as potent agonists at the recombinant human dopamine D4 receptor. J. Neurochem. 68: 804-12 [PMID:9003072]

227. Landwehrmeyer B, Mengod G and Palacios JM. (1993) Dopamine D3 receptor mRNA and binding sites in human brain. Brain Res. Mol. Brain Res. 18: 187-92 [PMID:8097550]

228. Landwehrmeyer B, Mengod $G$ and Palacios JM. (1993) Differential visualization of dopamine D2 and D3 receptor sites in rat brain. A comparative study using in situ hybridization histochemistry and ligand binding autoradiography. Eur. J. Neurosci. 5: 145-53 [PMID:8261096]

229. Lane JR, Donthamsetti P, Shonberg J, Draper-Joyce CJ, Dentry S, Michino M, Shi L, López L, Scammells PJ and Capuano B et al.. (2014) A new mechanism of allostery in a G protein-coupled receptor dimerNat. Chem. Biol. 10: 745-52 [PMID:25108820]

230. Lannfelt L, Sokoloff P, Martres MP, Pilon C, Giros B, Jonsson E, Sedvall G and Schwartz JC. (1992) Amino acid substitution in the dopamine $\mathrm{D}_{3}$ receptor as a useful polymorphism for investigating psychiatric disorders. Psychiatr. Genet. 2: 249-256

231. Laplante F, Sibley DR and Quirion R. (2004) Reduction in acetylcholine release in the hippocampus of dopamine D5 receptor-deficient mice. Neuropsychopharmacology 29: 1620-7 [PMID:15100705]

232. Le Foll B, Diaz J and Sokoloff P. (2005) Neuroadaptations to hyperdopaminergia in dopamine D3 receptordeficient mice. Life Sci 76: 1281-1296 [PMID:15642598]

233. Lee FJ, Xue S, Pei L, Vukusic B, Chéry N, Wang Y, Wang YT, Niznik HB, Yu XM and Liu F. (2002) Dual regulation of NMDA receptor functions by direct protein-protein interactions with the dopamine D1 receptor. Cell 111: 219-30 [PMID:12408866]

234. Lee SM, Yang Y and Mailman RB. (2014) Dopamine D1 receptor signaling: does GaQ-phospholipase C actually play a role? J. Pharmacol. Exp. Ther. 351: 9-17 [PMID:25052835]

235. Lejeune F and Millan MJ. (1995) Activation of dopamine D3 autoreceptors inhibits firing of ventral tegmental dopaminergic neurones in vivo. Eur. J. Pharmacol. 275: R7-9 [PMID:7768288]

236. Leopoldo M, Lacivita E, Contino M, Colabufo NA, Berardi F and Perrone R. (2007) Structure-activity relationship study on $\mathrm{N}-(1,2,3,4$-tetrahydronaphthalen-1-yl)-4-aryl-1-piperazinehexanamides, a class of 5HT7 receptor agents. 2. J. Med. Chem. 50: 4214-21 [PMID:17649988]

237. Leopoldo M, Lacivita E, De Giorgio P, Fracasso C, Guzzetti S, Caccia S, Contino M, Colabufo NA, Berardi F and Perrone R. (2008) Structural modifications of N-(1,2,3,4-tetrahydronaphthalen-1-yl)-4-aryl-1piperazinehexanamides: influence on lipophilicity and 5-HT7 receptor activity. Part III. J. Med. Chem. 51: 5813-22 [PMID:18800769]

238. Leriche L, Schwartz JC and Sokoloff P. (2003) The dopamine D3 receptor mediates locomotor hyperactivity induced by NMDA receptor blockade. Neuropharmacology 45: 174-81 [PMID:12842123]

239. Levant B, Grigoriadis DE and DeSouza EB. (1992) Characterization of [3H]quinpirole binding to D2-like dopamine receptors in rat brain. J. Pharmacol. Exp. Ther. 262: 929-35 [PMID:1356154]

240. Levant B and Vansell NR. (1997) In vivo occupancy of D2 dopamine receptors by nafadotride. Neuropsychopharmacology 17: 67-71 [PMID:9252981]

241. Levey AI, Hersch SM, Rye DB, Sunahara RK, Niznik HB, Kitt CA, Price DL, Maggio R, Brann MR and Ciliax BJ. (1993) Localization of D1 and D2 dopamine receptors in brain with subtype-specific antibodies. Proc. Natl. Acad. Sci. U.S.A. 90: 8861-5 [PMID:8415621] 
242. Li P, Zhang Q, Robichaud AJ, Lee T, Tomesch J, Yao W, Beard JD, Snyder GL, Zhu H and Peng Yet al.. (2014) Discovery of a tetracyclic quinoxaline derivative as a potent and orally active multifunctional drug candidate for the treatment of neuropsychiatric and neurological disorders. J. Med. Chem. 57: 2670-82 [PMID:24559051]

243. Limosin F, Loze JY, Rouillon F, Adès J and Gorwood P. (2003) Association between dopamine receptor D1 gene Ddel polymorphism and sensation seeking in alcohol-dependent men. Alcohol. Clin. Exp. Res. 27: 1226-8 [PMID:12966314]

244. Lin CW, Miller TR, Witte DG, Bianchi BR, Stashko M, Manelli AM and Frail DE. (1995) Characterization of cloned human dopamine D1 receptor-mediated calcium release in 293 cells. Mol. Pharmacol. 47: 131-9 [PMID:7838121]

245. Lindgren N, Usiello A, Goiny M, Haycock J, Erbs E, Greengard P, Hokfelt T, Borrelli E and Fisone G. (2003) Distinct roles of dopamine D2L and D2S receptor isoforms in the regulation of protein phosphorylation at presynaptic and postsynaptic sites. Proc. Natl. Acad. Sci. U.S.A. 100: 4305-9 [PMID:12651945]

246. Liu JC, Cox RF, Greif GJ, Freedman JE and Waszczak BL. (1994) The putative dopamine D3 receptor agonist 7-OH-DPAT: lack of mesolimbic selectivity. Eur J Pharmacol 264: 269-278 [PMID:7698165]

247. Liu LX, Monsma Jr FJ, Sibley DR and Chiodo LA. (1996) D2L, D2S, and D3 dopamine receptors stably transfected into NG108-15 cells couple to a voltage-dependent potassium current via distinct $G$ protein mechanisms. Synapse 24: 156-64 [PMID:8890457]

248. Liu XY, Mao LM, Zhang GC, Papasian CJ, Fibuch EE, Lan HX, Zhou HF, Xu M and Wang JQ. (2009) Activity-dependent modulation of limbic dopamine D3 receptors by CaMKII. Neuron 61: 425-38 [PMID:19217379]

249. Liu YF, Civelli O, Grandy DK and Albert PR. (1992) Differential sensitivity of the short and long human dopamine D2 receptor subtypes to protein kinase C. J. Neurochem. 59: 2311-7 [PMID:1331329]

250. Livak KJ, Rogers J and Lichter JB. (1995) Variability of dopamine D4 receptor (DRD4) gene sequence within and among nonhuman primate species. Proc. Natl. Acad. Sci. U.S.A. 92: 427-31 [PMID:7831304]

251. Lovenberg TW, Brewster WK, Mottola DM, Lee RC, Riggs RM, Nichols DE, Lewis MH and Mailman RB. (1989) Dihydrexidine, a novel selective high potency full dopamine D-1 receptor agonist. Eur. J. Pharmacol. 166: 111-3 [PMID:2572425]

252. Luippold G, Beilharz M, Wehrmann M, Unger L, Gross G and Mühlbauer B. (2005) Effect of dopamine D3 receptor blockade on renal function and glomerular size in diabetic rats. Naunyn Schmiedebergs Arch. Pharmacol. 371: 420-7 [PMID:15887004]

253. Luttrell LM, Roudabush FL, Choy EW, Miller WE, Field ME, Pierce KL and Lefkowitz RJ. (2001) Activation and targeting of extracellular signal-regulated kinases by beta-arrestin scaffolds. Proc. Natl. Acad. Sci. U.S.A. 98: 2449-54 [PMID:11226259]

254. Lévesque D, Diaz J, Pilon C, Martres MP, Giros B, Souil E, Schott D, Morgat JL, Schwartz JC and Sokoloff P. (1992) Identification, characterization, and localization of the dopamine D3 receptor in rat brain using 7[3H]hydroxy-N,N-di-n-propyl-2-aminotetralin. Proc. Natl. Acad. Sci. U.S.A. 89: 8155-9 [PMID:1518841]

255. MacKenzie RG, VanLeeuwen D, Pugsley TA, Shih YH, Demattos S, Tang L, Todd RD and O'Malley KL. (1994) Characterization of the human dopamine D3 receptor expressed in transfected cell lines. Eur. J. Pharmacol. 266: 79-85 [PMID:7907989]

256. Maeda K, Sugino H, Akazawa H, Amada N, Shimada J, Futamura T, Yamashita H, Ito N, McQuade RD and Mørk A et al.. (2014) Brexpiprazole I: in vitro and in vivo characterization of a novel serotonindopamine activity modulator. J. Pharmacol. Exp. Ther. 350: 589-604 [PMID:24947465]

257. Maggio R, Scarselli M, Novi F, Millan MJ and Corsini GU. (2003) Potent activation of dopamine D3/D2 heterodimers by the antiparkinsonian agents, S32504, pramipexole and ropinirole. J. Neurochem. 87: 63141 [PMID:14535946]

258. Mahan LC, Burch RM, Monsma FJ and Sibley DR. (1990) Expression of striatal D1 dopamine receptors coupled to inositol phosphate production and $\mathrm{Ca} 2+$ mobilization in Xenopus oocytes. Proc Natl Acad Sci U $S$ A 87: 2196-2200 [PMID:1690425] 
259. Maldonado R, Saiardi A, Valverde O, Samad TA, Roques BP and Borrelli E. (1997) Absence of opiate rewarding effects in mice lacking dopamine D2 receptors. Nature 388: 586-9 [PMID:9252189]

260. Malmberg A, Jackson DM, Eriksson A and Mohell N. (1993) Unique binding characteristics of antipsychotic agents interacting with human dopamine D2A, D2B, and D3 receptors. Mol. Pharmacol. 43: 749-54 [PMID:8099194]

261. Manor I, Corbex M, Eisenberg J, Gritsenkso I, Bachner-Melman R, Tyano S and Ebstein RP. (2004) Association of the dopamine D5 receptor with attention deficit hyperactivity disorder (ADHD) and scores on a continuous performance test (TOVA). Am J Med Genet B Neuropsychiatr Genet 127: 73-77 [PMID:15108184]

262. Mant R, Williams J, Asherson P, Parfitt E, McGuffin P and Owen MJ. (1994) Relationship between homozygosity at the dopamine D3 receptor gene and schizophrenia. Am. J. Med. Genet. 54: 21-6 [PMID:7909989]

263. Manzanedo C, Aguilar MA, Rodríguez-Arias M and Miñarro J. (2005) Sensitization to the rewarding effects of morphine depends on dopamine. Neuroreport 16: 201-5 [PMID:15671878]

264. Marcellino D, Ferré S, Casadó V, Cortés A, Le Foll B, Mazzola C, Drago F, Saur O, Stark H and Soriano A et al.. (2008) Identification of dopamine D1-D3 receptor heteromers. Indications for a role of synergistic D1D3 receptor interactions in the striatum. J. Biol. Chem. 283: 26016-25 [PMID:18644790]

265. Masri B, Salahpour A, Didriksen M, Ghisi V, Beaulieu JM, Gainetdinov RR and Caron MG. (2008) Antagonism of dopamine D2 receptor/beta-arrestin 2 interaction is a common property of clinically effective antipsychotics. Proc. Natl. Acad. Sci. U.S.A. 105: 13656-61 [PMID:18768802]

266. Matsui A, Matsuo H, Takanaga H, Sasaki S, Maeda M and Sawada Y. (1998) Prediction of catalepsies induced by amiodarone, aprindine and procaine: similarity in conformation of diethylaminoethyl side chain. J. Pharmacol. Exp. Ther. 287: 725-32 [PMID:9808703]

267. Matsumoto T, Ozono R, Sasaki N, Oshima T, Matsuura H, Kajiyama G, Carey RM and Kambe M. (2000) Type $1 \mathrm{~A}$ dopamine receptor expression in the heart is not altered in spontaneously hypertensive rats. Am. J. Hypertens. 13: 673-7 [PMID:10912752]

268. McAllister G, Knowles MR, Ward-Booth SM, Sinclair HA, Patel S, Marwood R, Emms F, Patel S, Smith A and Seabrook GR et al.. (1995) Functional coupling of human D2, D3, and D4 dopamine receptors in HEK293 cells. J. Recept. Signal Transduct. Res. 15: 267-81 [PMID:8903944]

269. McCall RB, Lookingland KJ, Bédard PJ and Huff RM. (2005) Sumanirole, a highly dopamine D2-selective receptor agonist: in vitro and in vivo pharmacological characterization and efficacy in animal models of Parkinson's disease. J. Pharmacol. Exp. Ther. 314: 1248-56 [PMID:15980060]

270. McElroy J, Zeller KL, Amy KA, Ward KA, Cawley JF, Mazzola AL, Keim W and Rohrbach K. (1993) In vivo agonist properties of 7-hydroxy-N,N-Di-N-propyl-2-aminotetralin, a dopamine D3-selective receptor ligand. Drug Development Research 30: 257-259

271. McQuade JA, Benoit SC, Xu M, Woods SC and Seeley RJ. (2004) High-fat diet induced adiposity in mice with targeted disruption of the dopamine-3 receptor gene. Behav. Brain Res. 151: 313-9 [PMID:15084447]

272. Meade JA, Free RB, Miller NR, Chun LS, Doyle TB, Moritz AE, Conroy JL, Watts VJ and Sibley DR. (2015) (-)-Stepholidine is a potent pan-dopamine receptor antagonist of both $\mathrm{G}$ protein- and $\beta$-arrestin-mediated signaling. Psychopharmacology (Berl.) 232: 917-30 [PMID:25231919]

273. Meador-Woodruff JH, Damask SP, Wang J, Haroutunian V, Davis KL and Watson SJ. (1996) Dopamine receptor mRNA expression in human striatum and neocortex. Neuropsychopharmacology 15: 17-29 [PMID:8797188]

274. Medvedev IO, Ramsey AJ, Masoud ST, Bermejo MK, Urs N, Sotnikova TD, Beaulieu JM, Gainetdinov RR and Salahpour A. (2013) D1 dopamine receptor coupling to PLC $\beta$ regulates forward locomotion in mice. J. Neurosci. 33: 18125-33 [PMID:24227722]

275. Mei YA, Griffon N, Buquet C, Martres MP, Vaudry H, Schwartz JC, Sokoloff P and Cazin L. (1995) Activation of dopamine D4 receptor inhibits an L-type calcium current in cerebellar granule cells. Neuroscience 68: 107-16 [PMID:7477916]

276. Mierau J, Schneider FJ, Ensinger HA, Chio CL, Lajiness ME and Huff RM. (1995) Pramipexole binding and 
activation of cloned and expressed dopamine D2, D3 and D4 receptors. Eur. J. Pharmacol. 290: 29-36 [PMID:7664822]

277. Millan MJ, Audinot V, Melon C and Newman-Tancredi A. (1995) Evidence that dopamine D3 receptors participate in clozapine-induced hypothermia. Eur. J. Pharmacol. 280: 225-9 [PMID:7589191]

278. Millan MJ, Audinot V, Rivet JM, Gobert A, Vian J, Prost JF, Spedding M and Peglion JL. (1994) S 14297, a novel selective ligand at cloned human dopamine D3 receptors, blocks 7-OH-DPAT-induced hypothermia in rats. Eur. J. Pharmacol. 260: R3-5 [PMID:7988633]

279. Millan MJ, Di Cara B, Dekeyne A, Panayi F, De Groote L, Sicard D, Cistarelli L, Billiras R and Gobert A. (2007) Selective blockade of dopamine $D(3)$ versus $D(2)$ receptors enhances frontocortical cholinergic transmission and social memory in rats: a parallel neurochemical and behavioural analysis. J. Neurochem. 100: 1047-61 [PMID:17266737]

280. Millan MJ, Gobert A, Newman-Tancredi A, Lejeune F, Cussac D, Rivet JM, Audinot V, Dubuffet T and Lavielle G. (2000) S33084, a novel, potent, selective, and competitive antagonist at dopamine D(3)receptors: I. Receptorial, electrophysiological and neurochemical profile compared with GR218,231 and L741,626. J. Pharmacol. Exp. Ther. 293: 1048-62 [PMID:10869410]

281. Millan MJ, Maiofiss L, Cussac D, Audinot V, Boutin JA and Newman-Tancredi A. (2002) Differential actions of antiparkinson agents at multiple classes of monoaminergic receptor. I. A multivariate analysis of the binding profiles of 14 drugs at 21 native and cloned human receptor subtypes. J. Pharmacol. Exp. Ther. 303: 791-804 [PMID:12388666]

282. Millan MJ, Peglion JL, Vian J, Rivet JM, Brocco M, Gobert A, Newman-Tancredi A, Dacquet C, Bervoets K and Girardon S. (1995) Functional correlates of dopamine D3 receptor activation in the rat in vivo and their modulation by the selective antagonist, (+)-S 14297: 1. Activation of postsynaptic D3 receptors mediates hypothermia, whereas blockade of $\mathrm{D} 2$ receptors elicits prolactin secretion and catalepsy. $J$ Pharmacol Exp Ther 275: 885-898 [PMID:7473180]

283. Minowa MT, Minowa T, Monsma FJ, Sibley DR and Mouradian MM. (1992) Characterization of the $5^{\prime}$ flanking region of the human $\mathrm{D}_{1 \mathrm{~A}}$ dopamine receptor gene. Proc. Natl. Acad. Sci. U.S.A. 89: 3045-3049 [PMID:1557411]

284. Misbahuddin A, Placzek MR, Chaudhuri KR, Wood NW, Bhatia KP and Warner TT. (2002) A polymorphism in the dopamine receptor DRD5 is associated with blepharospasm. Neurology 58: 124-6 [PMID:11781417]

285. Missale C, Nash SR, Robinson SW, Jaber M and Caron MG. (1998) Dopamine receptors: from structure to function. Physiol. Rev. 78: 189-225 [PMID:9457173]

286. Mizuo K, Narita M, Miyatake M and Suzuki T. (2004) Enhancement of dopamine-induced signaling responses in the forebrain of mice lacking dopamine D3 receptor. Neurosci. Lett. 358: 13-6 [PMID:15016423]

287. Monsma Jr FJ, Mahan LC, McVittie LD, Gerfen CR and Sibley DR. (1990) Molecular cloning and expression of a D1 dopamine receptor linked to adenylyl cyclase activation. Proc. Natl. Acad. Sci. U.S.A. 87: 6723-7 [PMID:2168556]

288. Montmayeur JP, Bausero P, Amlaiky N, Maroteaux L, Hen R and Borrelli E. (1991) Differential expression of the mouse D2 dopamine receptor isoforms. FEBS Lett. 278: 239-43 [PMID:1991517]

289. Montmayeur JP and Borrelli E. (1991) Transcription mediated by a cAMP-responsive promoter element is reduced upon activation of dopamine D2 receptors. Proc Natl Acad Sci U S A88: 3135-3139 [PMID:1849644]

290. Moreland RB, Patel M, Hsieh GC, Wetter JM, Marsh K and Brioni JD. (2005) A-412997 is a selective dopamine D4 receptor agonist in rats. Pharmacol. Biochem. Behav. 82: 140-7 [PMID:16153699]

291. Mulcrone $J$ and Kerwin RW. (1997) The regional pattern of D4 gene expression in human brainNeurosci. Lett. 234: 147-50 [PMID:9364519]

292. Mustard JA, Beggs KT and Mercer AR. (2005) Molecular biology of the invertebrate dopamine receptors. Arch. Insect Biochem. Physiol. 59: 103-17 [PMID:15986382]

293. Nakane M, Cowart MD, Hsieh GC, Miller L, Uchic ME, Chang R, Terranova MA, Donnelly-Roberts DL, 
Namovic MT and Miller TR et al.. (2005) 2-[4-(3,4-Dimethylphenyl)piperazin-1-ylmethyl]-1H benzoimidazole (A-381393), a selective dopamine D4 receptor antagonist. Neuropharmacology 49: 112-21 [PMID:15992586]

294. Narita M, Mizuo K, Mizoguchi H, Sakata M, Narita M, Tseng LF and Suzuki T. (2003) Molecular evidence for the functional role of dopamine D3 receptor in the morphine-induced rewarding effect and hyperlocomotion. J. Neurosci. 23: 1006-12 [PMID:12574430]

295. Narita M, Soma M, Tamaki H, Narita M and Suzuki T. (2002) Intensification of the development of ethanol dependence in mice lacking dopamine D(3) receptor. Neurosci. Lett. 324: 129-32 [PMID:11988344]

296. Nergårdh R, Oerther S and Fredholm BB. (2005) Differences between A 68930 and SKF 82958 could suggest synergistic roles of D1 and D5 receptors. Pharmacol. Biochem. Behav. 82: 495-505 [PMID:16318870]

297. Nir I, Harrison JM, Haque R, Low MJ, Grandy DK, Rubinstein M and luvone PM. (2002) Dysfunctional light-evoked regulation of CAMP in photoreceptors and abnormal retinal adaptation in mice lacking dopamine D4 receptors. J. Neurosci. 22: 2063-73 [PMID:11896146]

298. Nishi A, Snyder GL and Greengard P. (1997) Bidirectional regulation of DARPP-32 phosphorylation by dopamine. J. Neurosci. 17: 8147-55 [PMID:9334390]

299. Nürnberger A, Räbiger M, Mack A, Diaz J, Sokoloff P, Mühlbauer B and Luippold G. (2004) Subapical localization of the dopamine D3 receptor in proximal tubules of the rat kidney. J. Histochem. Cytochem. 52: 1647-55 [PMID:15557219]

300. O'Brien WT, Huang J, Buccafusca R, Garskof J, Valvezan AJ, Berry GT and Klein PS. (2011) Glycogen synthase kinase- 3 is essential for $\beta$-arrestin-2 complex formation and lithium-sensitive behaviors in mice.

J. Clin. Invest. 121: 3756-62 [PMID:21821916]

301. O'Connell DP, Botkin SJ, Ramos SI, Sibley DR, Ariano MA, Felder RA and Carey RM. (1995) Localization of dopamine D1A receptor protein in rat kidneys. Am. J. Physiol. 268: F1185-97 [PMID:7611459]

302. O'Hara CM, Uhland-Smith A, O'Malley KL and Todd RD. (1996) Inhibition of dopamine synthesis by dopamine D2 and D3 but not D4 receptors. J. Pharmacol. Exp. Ther. 277: 186-92 [PMID:8613917]

303. O'Malley KL, Harmon S, Tang L and Todd RD. (1992) The rat dopamine D4 receptor: sequence, gene structure, and demonstration of expression in the cardiovascular system. New Biol. 4: 137-46 [PMID:1554689]

304. O'Sullivan GJ, Dunleavy M, Hakansson K, Clementi M, Kinsella A, Croke DT, Drago J, Fienberg AA, Greengard P and Sibley DR et al.. (2008) Dopamine D1 vs D5 receptor-dependent induction of seizures in relation to DARPP-32, ERK1/2 and GluR1-AMPA signalling. Neuropharmacology 54: 1051-61 [PMID:18367215]

305. Oak JN, Lavine N and Van Tol HH. (2001) Dopamine D(4) and D(2L) Receptor Stimulation of the MitogenActivated Protein Kinase Pathway Is Dependent on trans-Activation of the Platelet-Derived Growth Factor Receptor. Mol. Pharmacol. 60: 92-103 [PMID:11408604]

306. Ochi T, Sakamoto M, Minamida A, Suzuki K, Ueda T, Une T, Toda H, Matsumoto K and Terauchi Y. (2005) Syntheses and properties of the major hydroxy metabolites in humans of blonanserin AD-5423, a novel antipsychotic agent. Bioorg. Med. Chem. Lett. 15: 1055-9 [PMID:15686911]

307. Onali P and Schwartz JP. (1983) Inhibition of VIP-sensitive adenylate cyclase by dopamine in rat anterior pituitary. Adv. Biochem. Psychopharmacol. 36: 199-207 [PMID:6344565]

308. Ozono R, O'Connell DP, Wang ZQ, Moore AF, Sanada H, Felder RA and Carey RM. (1997) Localization of the dopamine D1 receptor protein in the human heart and kidney. Hypertension 30: 725-9 [PMID:9323013]

309. Pan JQ, Lewis MC, Ketterman JK, Clore EL, Riley M, Richards KR, Berry-Scott E, Liu X, Wagner FF and Holson EB et al.. (2011) AKT kinase activity is required for lithium to modulate mood-related behaviors in mice. Neuropsychopharmacology 36: 1397-411 [PMID:21389981]

310. Parsian A, Chakraverty S and Todd RD. (1995) Possible association between the dopamine D3 receptor gene and bipolar affective disorder. Am. J. Med. Genet. 60: 234-7 [PMID:7573178]

311. Parsons B, Stanley M and Javitch J. (1993) Differential visualization of dopamine D2 and D3 receptors in rat brain. Eur. J. Pharmacol. 234: 269-72 [PMID:8097723] 
312. Patel MV, Kolasa T, Mortell K, Matulenko MA, Hakeem AA, Rohde JJ, Nelson SL, Cowart MD, Nakane M and Miller LN et al.. (2006) Discovery of 3-methyl-N-(1-oxy-3',4',5',6'-tetrahydro-2'H-[2,4'-bipyridine]-1'ylmethyl)benzamide (ABT-670), an orally bioavailable dopamine D4 agonist for the treatment of erectile dysfunction. J. Med. Chem. 49: 7450-65 [PMID:17149874]

313. Patel S, Freedman S, Chapman KL, Emms F, Fletcher AE, Knowles M, Marwood R, Mcallister G, Myers J and Curtis $N$ et al.. (1997) Biological profile of L-745,870, a selective antagonist with high affinity for the dopamine D4 receptor. J. Pharmacol. Exp. Ther. 283: 636-47 [PMID:9353380]

314. Patel S, Patel S, Marwood R, Emms F, Marston D, Leeson PD, Curtis NR, Kulagowski JJ and Freedman SB. (1996) Identification and pharmacological characterization of [125I]L-750,667, a novel radioligand for the dopamine D4 receptor. Mol. Pharmacol. 50: 1658-64 [PMID:8967990]

315. Pedersen UB, Norby B, Jensen AA, Schiødt M, Hansen A, Suhr-Jessen P, Scheideler M, Thastrup $O$ and Andersen PH. (1994) Characteristics of stably expressed human dopamine D1a and D1b receptors: atypical behavior of the dopamine D1b receptor. Eur. J. Pharmacol. 267: 85-93 [PMID:8206133]

316. Peng XQ, Ashby Jr CR, Spiller K, Li X, Li J, Thomasson N, Millan MJ, Mocaër E, Muńoz C and Gardner EL et al.. (2009) The preferential dopamine D3 receptor antagonist S33138 inhibits cocaine reward and cocaine-triggered relapse to drug-seeking behavior in rats. Neuropharmacology 56: 752-60 [PMID:19136017]

317. Perachon S, Betancur C, Pilon C, Rostène W, Schwartz JC and Sokoloff P. (2000) Role of dopamine D3 receptors in thermoregulation: a reappraisal. Neuroreport 11: 221-5 [PMID:10683862]

318. Perachon S, Schwartz JC and Sokoloff P. (1999) Functional potencies of new antiparkinsonian drugs at recombinant human dopamine D1, D2 and D3 receptors. Eur. J. Pharmacol. 366: 293-300 [PMID:10082211]

319. Perreault ML, Hasbi A, Alijaniaram M, Fan T, Varghese G, Fletcher PJ, Seeman P, O'Dowd BF and George SR. (2010) The dopamine D1-D2 receptor heteromer localizes in dynorphin/enkephalin neurons: increased high affinity state following amphetamine and in schizophrenia. J. Biol. Chem. 285: 36625-34 [PMID:20864528]

320. Pilla M, Perachon S, Sautel F, Garrido F, Mann A, Wermuth CG, Schwartz JC, Everitt BJ and Sokoloff P. (1999) Selective inhibition of cocaine-seeking behaviour by a partial dopamine D3 receptor agonist. Nature 400: 371-5 [PMID:10432116]

321. Pillai G, Brown NA, McAllister G, Milligan G and Seabrook GR. (1998) Human D2 and D4 dopamine receptors couple through betagamma G-protein subunits to inwardly rectifying $\mathrm{K}+$ channels (GIRK1) in a Xenopus oocyte expression system: selective antagonism by L-741,626 and L-745,870 respectively. Neuropharmacology 37: 983-987 [PMID:9833627]

322. Pilon C, Lévesque D, Dimitriadou V, Griffon N, Martres MP, Schwartz JC and Sokoloff P. (1994) Functional coupling of the human dopamine D3 receptor in a transfected NG 108-15 neuroblastoma-glioma hybrid cell line. Eur. J. Pharmacol. 268: 129-39 [PMID:7957635]

323. Placzek MR, Misbahuddin A, Chaudhuri KR, Wood NW, Bhatia KP and Warner TT. (2001) Cervical dystonia is associated with a polymorphism in the dopamine (D5) receptor gene. $J$ Neurol Neurosurg Psychiatry 71: 262-264 [PMID:11459908]

324. Potenza MN, Graminski GF, Schmauss C and Lerner MR. (1994) Functional expression and characterization of human D2 and D3 dopamine receptors. J. Neurosci. 14: 1463-76 [PMID:7907363]

325. Pou C, Mannoury la Cour C, Stoddart LA, Millan MJ and Milligan G. (2012) Functional homomers and heteromers of dopamine D2L and D3 receptors co-exist at the cell surface. J. Biol. Chem. 287: 8864-78 [PMID:22291025]

326. Primus RJ, Thurkauf A, Xu J, Yevich E, Mclnerney S, Shaw K, Tallman JF and Gallagher DW. (1997) II. Localization and characterization of dopamine D4 binding sites in rat and human brain by use of the novel, D4 receptor-selective ligand [3H]NGD 94-1. J. Pharmacol. Exp. Ther. 282: 1020-7 [PMID:9262371]

327. Pugsley TA, Davis MD, Akunne HC, MacKenzie RG, Shih YH, Damsma G, Wikstrom H, Whetzel SZ, Georgic LM and Cooke LW et al.. (1995) Neurochemical and functional characterization of the preferentially selective dopamine D3 agonist PD 128907. J. Pharmacol. Exp. Ther. 275: 1355-66 
[PMID:8531103]

328. Radl D, De Mei C, Chen E, Lee H and Borrelli E. (2013) Each individual isoform of the dopamine D2 receptor protects from lactotroph hyperplasia. Mol. Endocrinol. 27: 953-65 [PMID:23608643]

329. Ralph RJ, Varty GB, Kelly MA, Wang YM, Caron MG, Rubinstein M, Grandy DK, Low MJ and Geyer MA. (1999) The dopamine D2, but not D3 or D4, receptor subtype is essential for the disruption of prepulse inhibition produced by amphetamine in mice. J. Neurosci. 19: 4627-33 [PMID:10341260]

330. Rashid AJ, So CH, Kong MM, Furtak T, El-Ghundi M, Cheng R, O'Dowd BF and George SR. (2007) D1D2 dopamine receptor heterooligomers with unique pharmacology are coupled to rapid activation of $\mathrm{Gq} / 11$ in the striatum. Proc. Natl. Acad. Sci. U.S.A. 104: 654-9 [PMID:17194762]

331. Reavill C, Taylor SG, Wood MD, Ashmeade T, Austin NE, Avenell KY, Boyfield I, Branch CL, Cilia J and Coldwell MC et al.. (2000) Pharmacological actions of a novel, high-affinity, and selective human dopamine D(3) receptor antagonist, SB-277011-A. J. Pharmacol. Exp. Ther. 294: 1154-65 [PMID:10945872]

332. Ricci A and Amenta F. (1994) Dopamine D5 receptors in human peripheral blood lymphocytes: a radioligand binding study. J. Neuroimmunol. 53: 1-7 [PMID:8051291]

333. Ricci A, Mignini F, Tomassoni D and Amenta F. (2006) Dopamine receptor subtypes in the human pulmonary arterial tree. Auton Autacoid Pharmacol 26: 361-9 [PMID:16968475]

334. Ricci A, Vega JA, Mammola CL and Amenta F. (1995) Localisation of dopamine D3 receptor in the rat cerebellar cortex: a light microscope autoradiographic study. Neurosci. Lett. 190: 163-6 [PMID:7637884]

335. Ricci A, Veglio F and Amenta F. (1995) Radioligand binding characterization of putative dopamine D3 receptor in human peripheral blood lymphocytes with [3H]7-OH-DPAT. J. Neuroimmunol. 58: 139-44 [PMID:7759603]

336. Rivera A, Peñafiel A, Megías M, Agnati LF, López-Téllez JF, Gago B, Gutiérrez A, de la Calle A and Fuxe K. (2008) Cellular localization and distribution of dopamine $D(4)$ receptors in the rat cerebral cortex and their relationship with the cortical dopaminergic and noradrenergic nerve terminal networks. Neuroscience 155: 997-1010 [PMID:18620029]

337. Rivera A, Trías S, Peñafiel A, Angel Narváez J, Díaz-Cabiale Z, Moratalla R and de la Calle A. (2003) Expression of D4 dopamine receptors in striatonigral and striatopallidal neurons in the rat striatum. Brain Res. 989: 35-41 [PMID:14519509]

338. Rivet JM, Audinot V, Gobert A, Peglion JL and Millan MJ. (1994) Modulation of mesolimbic dopamine release by the selective dopamine D3 receptor antagonist, (+)-S 14297. Eur. J. Pharmacol. 265: 175-7 [PMID:7875234]

339. Rocchetti J, Isingrini E, Dal Bo G, Sagheby S, Menegaux A, Tronche F, Levesque D, Moquin L, Gratton A and Wong TP et al.. (2015) Presynaptic D2 dopamine receptors control long-term depression expression and memory processes in the temporal hippocampus. Biol. Psychiatry 77: 513-25 [PMID:24742619]

340. Rouge-Pont F, Usiello A, Benoit-Marand M, Gonon F, Piazza PV and Borrelli E. (2002) Changes in extracellular dopamine induced by morphine and cocaine: crucial control by D2 receptors. J. Neurosci. 22: 3293-301 [PMID:11943831]

341. Rowley M, Broughton HB, Collins I, Baker R, Emms F, Marwood R, Patel S, Patel S, Ragan Cl and Freedman SB et al.. (1996) 5-(4-Chlorophenyl)-4-methyl-3-(1-(2-phenylethyl)piperidin-4-yl)isoxazole: a potent, selective antagonist at human cloned dopamine D4 receptors. J. Med. Chem. 39: 1943-5 [PMID:8642551]

342. Rubinstein M, Phillips TJ, Bunzow JR, Falzone TL, Dziewczapolski G, Zhang G, Fang Y, Larson JL, McDougall JA, Chester JA, Saez C, Pugsley TA, Gershanik O, Low MJ and Grandy DK. (1997) Mice lacking dopamine $D_{4}$ receptors are supersensitive to ethanol, cocaine, and methamphetamine.Cell 90 : 991-1001 [PMID:9323127]

343. Ryman-Rasmussen JP, Griffith A, Oloff S, Vaidehi N, Brown JT, Goddard 3rd WA and Mailman RB. (2007) Functional selectivity of dopamine $\mathrm{D} 1$ receptor agonists in regulating the fate of internalized receptors. Neuropharmacology 52: 562-75 [PMID:17067639]

344. Saiardi A and Borrelli E. (1998) Absence of dopaminergic control on melanotrophs leads to Cushing's-like syndrome in mice. Mol. Endocrinol. 12: 1133-9 [PMID:9717839] 
345. Saiardi A, Bozzi Y, Baik JH and Borrelli E. (1997) Antiproliferative role of dopamine: loss of D2 receptors causes hormonal dysfunction and pituitary hyperplasia. Neuron 19: 115-26 [PMID:9247268]

346. Sanger DJ, Depoortere R and Perrault G. (1996) Evidence for a role for dopamine D3 receptors in the effects of dopamine agonists on operant behaviour in rats. Behav Pharmacol 7: 477-482 [PMID:11224444]

347. Santini E, Feyder M, Gangarossa G, Bateup HS, Greengard P and Fisone G. (2012) Dopamine- and cAMP-regulated phosphoprotein of 32-kDa (DARPP-32)-dependent activation of extracellular signalregulated kinase (ERK) and mammalian target of rapamycin complex 1 (mTORC1) signaling in experimental parkinsonism. J. Biol. Chem. 287: 27806-12 [PMID:22753408]

348. Santini E, Heiman M, Greengard P, Valjent E and Fisone G. (2009) Inhibition of mTOR signaling in Parkinson's disease prevents L-DOPA-induced dyskinesia. Sci Signa/2: ra36 [PMID:19622833]

349. Santini E, Valjent E, Usiello A, Carta M, Borgkvist A, Girault JA, Hervé D, Greengard P and Fisone G. (2007) Critical involvement of CAMP/DARPP-32 and extracellular signal-regulated protein kinase signaling in L-DOPA-induced dyskinesia. J. Neurosci. 27: 6995-7005 [PMID:17596448]

350. Sasse BC, Mach UR, Leppaenen J, Calmels T and Stark H. (2007) Hybrid approach for the design of highly affine and selective dopamine $D(3)$ receptor ligands using privileged scaffolds of biogenic amine GPCR ligands. Bioorg. Med. Chem. 15: 7258-73 [PMID:17826096]

351. Sato M, Soma M, Nakayama T and Kanmatsuse K. (2000) Dopamine D1 receptor gene polymorphism is associated with essential hypertension. Hypertension 36: 183-6 [PMID:10948075]

352. Sautel F, Griffon N, Lévesque D, Pilon C, Schwartz JC and Sokoloff P. (1995) A functional test identifies dopamine agonists selective for $\mathrm{D}_{3}$ versus $\mathrm{D}_{2}$ receptors. Neuroreport 6: 329-332 [PMID:7756621]

353. Sautel F, Griffon N, Sokoloff P, Schwartz JC, Launay C, Simon P, Costentin J, Schoenfelder A, Garrido F and Mann A et al.. (1995) Nafadotride, a potent preferential dopamine D3 receptor antagonist, activates locomotion in rodents. J. Pharmacol. Exp. Ther. 275: 1239-46 [PMID:8531087]

354. Scarselli M, Novi F, Schallmach E, Lin R, Baragli A, Colzi A, Griffon N, Corsini GU, Sokoloff P and Levenson $\mathrm{R}$ et al.. (2001) D2/D3 dopamine receptor heterodimers exhibit unique functional properties.J. Biol. Chem. 276: 30308-14 [PMID:11373283]

355. Schetz JA, Benjamin PS and Sibley DR. (2000) Nonconserved residues in the second transmembranespanning domain of the $D(4)$ dopamine receptor are molecular determinants of $D(4)$-selective pharmacology. Mol. Pharmacol. 57: 144-52 [PMID:10617689]

356. Schilström B, Yaka R, Argilli E, Suvarna N, Schumann J, Chen BT, Carman M, Singh V, Mailliard WS and Ron D et al.. (2006) Cocaine enhances NMDA receptor-mediated currents in ventral tegmental area cells via dopamine D5 receptor-dependent redistribution of NMDA receptors. J. Neurosci. 26: 8549-58 [PMID:16914681]

357. Schinelli S, Paolillo M and Corona GL. (1994) Opposing actions of D1- and D2-dopamine receptors on arachidonic acid release and cyclic AMP production in striatal neurons. J. Neurochem. 62: 944-9 [PMID:8113815]

358. Schlachter SK, Poel TJ, Lawson CF, Dinh DM, Lajiness ME, Romero AG, Rees SA, Duncan JN and Smith MW. (1997) Substituted 4-aminopiperidines having high in vitro affinity and selectivity for the cloned human dopamine D4 receptor. Eur. J. Pharmacol. 322: 283-6 [PMID:9098699]

359. Schmauss C, Haroutunian V, Davis KL and Davidson M. (1993) Selective loss of dopamine D3-type receptor mRNA expression in parietal and motor cortices of patients with chronic schizophrenia. Proc. Natl. Acad. Sci. U.S.A. 90: 8942-6 [PMID:8415635]

360. Schmitz Y, Schmauss $C$ and Sulzer D. (2002) Altered dopamine release and uptake kinetics in mice lacking D2 receptors. J. Neurosci. 22: 8002-9 [PMID:12223553]

361. Schoots $\mathrm{O}$ and Van Tol HH. (2003) The human dopamine D4 receptor repeat sequences modulate expression. Pharmacogenomics J. 3: 343-8 [PMID:14581929]

362. Schotte A, Janssen PF, Gommeren W, Luyten WH, Van Gompel P, Lesage AS, De Loore K and Leysen JE. (1996) Risperidone compared with new and reference antipsychotic drugs: in vitro and in vivo receptor binding. Psychopharmacology (Berl.) 124: 57-73 [PMID:8935801]

363. Schwartz JC Carlsson A Caron M Scatton B Civelli O Kebabian JW Langer SZ Sedvall G Seeman P 
Spano PF Sokoloff P Van Tol H. (1998) Dopamine receptors. In The IUPHAR Compendium of Receptor Characterization and Classification Edited by Girdlestone D: IUPHAR media: 141-151

364. Seabrook GR, Patel S, Marwood R, Emms F, Knowles MR, Freedman SB and McAllister G. (1992) Stable expression of human D3 dopamine receptors in GH4C1 pituitary cells. FEBS Lett. 312: 123-6 [PMID:1330688]

365. Seeman P. (2001) Antipsychotic drugs, dopamine receptors, and schizophrenia.Clinical Neuroscience Research 1: 53-60

366. Seeman P, Chau-Wong M, Tedesco J and Wong K. (1975) Brain receptors for antipsychotic drugs and dopamine: direct binding assays. Proc. Natl. Acad. Sci. U.S.A. 72: 4376-80 [PMID:1060115]

367. Seeman $P$, Corbett $R$ and Van Tol HH. (1997) Atypical neuroleptics have low affinity for dopamine D2 receptors or are selective for D4 receptors. Neuropsychopharmacology 16: 93-110; discussion 111-35 [PMID:9015795]

368. Seeman P, Guan HC, Van Tol HH and Niznik HB. (1993) Low density of dopamine D4 receptors in Parkinson's, schizophrenia, and control brain striata. Synapse 14: 247-253 [PMID:8248849]

369. Seeman P and Tallerico T. (1998) Antipsychotic drugs which elicit little or no parkinsonism bind more loosely than dopamine to brain D2 receptors, yet occupy high levels of these receptors. Mol. Psychiatry 3 : 123-34 [PMID:9577836]

370. Serý O, Drtílková I, Theiner P, Pitelová R, Staif R, Znojil V, Lochman J and Didden W. (2006) Polymorphism of DRD2 gene and ADHD. Neuro Endocrinol. Lett. 27: 236-40 [PMID:16648784]

371. Setlow B and McGaugh JL. (2000) D2 dopamine receptor blockade immediately post-training enhances retention in hidden and visible platform versions of the water maze. Learn. Mem. 7: 187-91 [PMID:10837508]

372. Severino G, Congiu D, Serreli C, De Lisa R, Chillotti C, Del Zompo M and Piccardi MP. (2005) A48G polymorphism in the D1 receptor genes associated with bipolar I disorder. Am. J. Med. Genet. B Neuropsychiatr. Genet. 134B: 37-8 [PMID:15704231]

373. Shahid M, Walker GB, Zorn SH and Wong EH. (2009) Asenapine: a novel psychopharmacologic agent with a unique human receptor signature. J. Psychopharmacol. (Oxford) 23: 65-73 [PMID:18308814]

374. Shih YH, Chung FZ and Pugsley TA. (1997) Cloning, expression and characterization of a human dopamine D4.2 receptor (CHO K1 cells) and various D4.2/D2L chimeras (COS-7 cells). Prog. Neuropsychopharmacol. Biol. Psychiatry 21: 153-67 [PMID:9075264]

375. Shin Y, Kumar U, Patel Y, Patel SC and Sidhu A. (2003) Differential expression of D2-like dopamine receptors in the kidney of the spontaneously hypertensive rat. J. Hypertens. 21: 199-207 [PMID:12544452]

376. Sibley DR and Monsma Jr FJ. (1992) Molecular biology of dopamine receptors.Trends Pharmacol. Sci. 13: 61-9 [PMID:1561715]

377. Skaaning Jensen B, Levavi-Sivan B, Fishburn CS and Fuchs S. (1997) Functional expression of the murine D2, D3, and D4 dopamine receptors in Xenopus laevis oocytes. FEBS Lett 420: 191-195 [PMID:9459308]

378. Snyder GL, Vanover KE, Zhu H, Miller DB, O'Callaghan JP, Tomesch J, Li P, Zhang Q, Krishnan V and Hendrick JP et al.. (2015) Functional profile of a novel modulator of serotonin, dopamine, and glutamate neurotransmission. Psychopharmacology (Berl.) 232: 605-21 [PMID:25120104]

379. So CH, Varghese G, Curley KJ, Kong MM, Alijaniaram M, Ji X, Nguyen T, O'dowd BF and George SR. (2005) D1 and D2 dopamine receptors form heterooligomers and cointernalize after selective activation of either receptor. Mol. Pharmacol. 68: 568-78 [PMID:15923381]

380. Sokoloff P, Andrieux M, Besançon R, Pilon C, Martres MP, Giros B and Schwartz JC. (1992) Pharmacology of human dopamine D3 receptor expressed in a mammalian cell line: comparison with D2 receptor. Eur. J. Pharmacol. 225: 331-7 [PMID:1354163]

381. Sokoloff P, Giros B, Martres MP, Andrieux M, Besancon R, Pilon C, Bouthenet ML, Souil E and Schwartz JC. (1992) Localization and function of the D3 dopamine receptor. Arzneimittelforschung 42: 224-30 [PMID:1586393]

382. Sokoloff P, Giros B, Martres MP, Bouthenet ML and Schwartz JC. (1990) Molecular cloning and 
characterization of a novel dopamine receptor (D3) as a target for neuroleptics. Nature 347: 146-51 [PMID:1975644]

383. Sokoloff P, Leriche L, Diaz J, Louvel J and Pumain R. (2013) Direct and indirect interactions of the dopamine $D_{3}$ receptor with glutamate pathways: implications for the treatment of schizophrenia. Naunyn Schmiedebergs Arch. Pharmacol. 386: 107-24 [PMID:23001156]

384. Sokoloff P and Schwartz JC. (1995) Novel dopamine receptors half a decade later. Trends Pharmacol. Sci. 16: 270-5 [PMID:7482988]

385. Song R, Zhang HY, Li X, Bi GH, Gardner EL and Xi ZX. (2012) Increased vulnerability to cocaine in mice lacking dopamine D3 receptors. Proc. Natl. Acad. Sci. U.S.A. 109: 17675-80 [PMID:23045656]

386. Souza BR, Romano-Silva MA and Tropepe V. (2011) Dopamine D2 receptor activity modulates Akt signaling and alters GABAergic neuron development and motor behavior in zebrafish larvae. J. Neurosci. 31: 5512-25 [PMID:21471388]

387. Spano PF, Govoni S and Trabucchi M. (1978) Studies on the pharmacological properties of dopamine receptors in various areas of the central nervous system. Adv. Biochem. Psychopharmacol. 19: 155-65 [PMID:358777]

388. Spetea M, Berzetei-Gurske IP, Guerrieri E and Schmidhammer H. (2012) Discovery and pharmacological evaluation of a diphenethylamine derivative (HS665), a highly potent and selective $\mathrm{k}$ opioid receptor agonist. J. Med. Chem. 55: 10302-6 [PMID:23134120]

389. Stanwood GD, Parlaman JP and Levitt P. (2005) Anatomical abnormalities in dopaminoceptive regions of the cerebral cortex of dopamine D1 receptor mutant mice. J. Comp. Neurol. 487: 270-82 [PMID:15892099]

390. Starr BS and Starr MS. (1986) Differential effects of dopamine D1 and D2 agonists and antagonists on velocity of movement, rearing and grooming in the mouse. Implications for the roles of D1 and D2 receptors. Neuropharmacology 25: 455-63 [PMID:3488514]

391. Starr MS and Starr BS. (1995) Motor actions of 7-OH-DPAT in normal and reserpine-treated mice suggest involvement of both dopamine D2 and D3 receptors. Eur. J. Pharmacol. 277: 151-8 [PMID:7493603]

392. Steiner H, Fuchs S and Accili D. (1997) D3 dopamine receptor-deficient mouse: evidence for reduced anxiety. Physiol. Behav. 63: 137-41 [PMID:9402626]

393. Strupczewski JT, Bordeau KJ, Chiang Y, Glamkowski EJ, Conway PG, Corbett R, Hartman HB, Szewczak MR, Wilmot CA and Helsley GC. (1995) 3-[[(Aryloxy)alkyl]piperidinyl]-1,2-benzisoxazoles as D2/5-HT2 antagonists with potential atypical antipsychotic activity: antipsychotic profile of iloperidone (HP 873). J. Med. Chem. 38: 1119-31 [PMID:7707315]

394. Subramaniam S, Napolitano F, Mealer RG, Kim S, Errico F, Barrow R, Shahani N, Tyagi R, Snyder SH and Usiello A. (2012) Rhes, a striatal-enriched small G protein, mediates mTOR signaling and L-DOPAinduced dyskinesia. Nat. Neurosci. 15: 191-3 [PMID:22179112]

395. Sun D, Wilborn TW and Schafer JA. (1998) Dopamine D4 receptor isoform mRNA and protein are expressed in the rat cortical collecting duct. Am. J. Physiol. 275: F742-51 [PMID:9815131]

396. Sun WC, Jin L, Cao Y, Wang LZ, Meng F and Zhu XZ. (2005) Cloning, expression, and functional analysis of human dopamine D1 receptors. Acta Pharmacol. Sin. 26: 27-32 [PMID:15659110]

397. Sunahara RK, Guan HC, O'Dowd BF, Seeman P, Laurier LG, Ng G, George SR, Torchia J, Van Tol HH and Niznik HB. (1991) Cloning of the gene for a human dopamine D5 receptor with higher affinity for dopamine than D1. Nature 350: 614-9 [PMID:1826762]

398. Sunahara RK, Niznik HB, Weiner DM, Stormann TM, Brann MR, Kennedy JL, Gelernter JE, Rozmahel R, Yang YL and Israel $Y$ et al.. (1990) Human dopamine D1 receptor encoded by an intronless gene on chromosome 5. Nature 347: 80-3 [PMID:1975640]

399. Sunohara GA, Roberts W, Malone M, Schachar RJ, Tannock R, Basile VS, Wigal T, Wigal SB, Schuck S, Moriarty J, Swanson JM, Kennedy JL and Barr CL. (2000) Linkage of the dopamine D4 receptor gene and attention-deficit/hyperactivity disorder. J Am Acad Child Adolesc Psychiatry39: 1537-1542 [PMID:11128331]

400. Suzuki T, Kobayashi K and Nagatsu T. (1995) Genomic structure and tissue distribution of the mouse dopamine D4 receptor. Neurosci Lett 199: 69-72 [PMID:8584230] 
401. Svenningsson P, Lindskog M, Rognoni F, Fredholm BB, Greengard P and Fisone G. (1998) Activation of adenosine A2A and dopamine D1 receptors stimulates cyclic AMP-dependent phosphorylation of DARPP32 in distinct populations of striatal projection neurons. Neuroscience 84: 223-8 [PMID:9522376]

402. Svenningsson P, Nishi A, Fisone G, Girault JA, Nairn AC and Greengard P. (2004) DARPP-32: an integrator of neurotransmission. Annu. Rev. Pharmacol. Toxicol. 44: 269-96 [PMID:14744247]

403. Svensson K, Carlsson A, Huff RM, Kling-Petersen T and Waters N. (1994) Behavioral and neurochemical data suggest functional differences between dopamine D2 and D3 receptors. Eur. J. Pharmacol. 263: 23543 [PMID:7843260]

404. Svensson K, Carlsson A and Waters N. (1994) Locomotor inhibition by the D3 ligand R-(+)-7-OH-DPAT is independent of changes in dopamine release. J. Neural Transm. Gen. Sect. 95: 71-4 [PMID:7857588]

405. Svingos AL, Periasamy S and Pickel VM. (2000) Presynaptic dopamine D(4) receptor localization in the rat nucleus accumbens shell. Synapse 36: 222-32 [PMID:10819901]

406. Swift JL, Godin AG, Doré K, Freland L, Bouchard N, Nimmo C, Sergeev M, De Koninck Y, Wiseman PW and Beaulieu JM. (2011) Quantification of receptor tyrosine kinase transactivation through direct dimerization and surface density measurements in single cells. Proc. Natl. Acad. Sci. U.S.A. 108: 7016-21 [PMID:21482778]

407. Tadori Y, Forbes RA, McQuade RD and Kikuchi T. (2011) Functional potencies of dopamine agonists and antagonists at human dopamine $\mathrm{D}_{2}$ and $\mathrm{D}_{3}$ receptors. Eur. J. Pharmacol. 666: 43-52 [PMID:21658377]

408. Tallman JF, Primus RJ, Brodbeck R, Cornfield L, Meade R, Woodruff K, Ross P, Thurkauf A and Gallager DW. (1997) I. NGD 94-1: identification of a novel, high-affinity antagonist at the human dopamine D4 receptor. J. Pharmacol. Exp. Ther. 282: 1011-9 [PMID:9262370]

409. Tang L, Todd RD, Heller A and O'Malley KL. (1994) Pharmacological and functional characterization of D2, D3 and D4 dopamine receptors in fibroblast and dopaminergic cell lines. J. Pharmacol. Exp. Ther. 268: 495-502 [PMID:8301592]

410. Tang L, Todd RD and O'Malley KL. (1994) Dopamine D2 and D3 receptors inhibit dopamine releaseJ. Pharmacol. Exp. Ther. 270: 475-9 [PMID:8071839]

411. Tarantino LM, Feiner L, Alavizadeh A, Wiltshire T, Hurle B, Ornitz DM, Webber AL, Raper J, Lengeling A and Rowe LB et al.. (2000) A high-resolution radiation hybrid map of the proximal portion of mouse chromosome 5. Genomics 66: 55-64 [PMID:10843805]

412. Thomas TC, Grandy DK, Gerhardt GA and Glaser PE. (2009) Decreased dopamine D4 receptor expression increases extracellular glutamate and alters its regulation in mouse striatum.

Neuropsychopharmacology 34: 436-45 [PMID:18536704]

413. Thomas TC, Kruzich PJ, Joyce BM, Gash CR, Suchland K, Surgener SP, Rutherford EC, Grandy DK, Gerhardt GA and Glaser PE. (2007) Dopamine D4 receptor knockout mice exhibit neurochemical changes consistent with decreased dopamine release. J. Neurosci. Methods 166: 306-14 [PMID:17449106]

414. Tiberi M and Caron MG. (1994) High agonist-independent activity is a distinguishing feature of the dopamine D1B receptor subtype. J. Biol. Chem. 269: 27925-31 [PMID:7525564]

415. Tiberi M, Jarvie KR, Silvia C, Falardeau P, Gingrich JA, Godinot N, Bertrand L, Yang-Feng TL, Fremeau Jr RT and Caron MG. (1991) Cloning, molecular characterization, and chromosomal assignment of a gene encoding a second D1 dopamine receptor subtype: differential expression pattern in rat brain compared with the D1A receptor. Proc. Natl. Acad. Sci. U.S.A. 88: 7491-5 [PMID:1831904]

416. Tice MA, Hashemi T, Taylor LA, Duffy RA and McQuade RD. (1994) Characterization of the binding of SCH 39166 to the five cloned dopamine receptor subtypes. Pharmacol. Biochem. Behav. 49: 567-71 [PMID:7862709]

417. Toda S, Alguacil LF and Kalivas PW. (2003) Repeated cocaine administration changes the function and subcellular distribution of adenosine A1 receptor in the rat nucleus accumbens. J. Neurochem. 87: 147884 [PMID:14713303]

418. Tran AH, Tamura R, Uwano T, Kobayashi T, Katsuki M, Matsumoto G and Ono T. (2002) Altered accumbens neural response to prediction of reward associated with place in dopamine $\mathrm{D} 2$ receptor knockout mice. Proc. Natl. Acad. Sci. U.S.A. 99: 8986-91 [PMID:12084937] 
419. Undie AS and Friedman E. (1990) Stimulation of a dopamine D1 receptor enhances inositol phosphates formation in rat brain. J. Pharmacol. Exp. Ther. 253: 987-92 [PMID:1972756]

420. Urs NM, Daigle TL and Caron MG. (2011) A dopamine D1 receptor-dependent $\beta$-arrestin signaling complex potentially regulates morphine-induced psychomotor activation but not reward in mice. Neuropsychopharmacology 36: 551-8 [PMID:20980993]

421. Urs NM, Snyder JC, Jacobsen JP, Peterson SM and Caron MG. (2012) Deletion of GSK3 $\beta$ in D2Rexpressing neurons reveals distinct roles for $\beta$-arrestin signaling in antipsychotic and lithium action. Proc. Natl. Acad. Sci. U.S.A. 109: 20732-7 [PMID:23188793]

422. Usiello A, Baik JH, Rougé-Pont F, Picetti R, Dierich A, LeMeur M, Piazza PV and Borrelli E. (2000) Distinct functions of the two isoforms of dopamine D2 receptors. Nature 408: 199-203 [PMID:11089973]

423. Valjent E, Bertran-Gonzalez J, Bowling H, Lopez S, Santini E, Matamales M, Bonito-Oliva A, Hervé D, Hoeffer $C$ and Klann E et al.. (2011) Haloperidol regulates the state of phosphorylation of ribosomal protein S6 via activation of PKA and phosphorylation of DARPP-32. Neuropsychopharmacology 36: 2561-70 [PMID:21814187]

424. Valjent E, Pascoli V, Svenningsson P, Paul S, Enslen H, Corvol JC, Stipanovich A, Caboche J, Lombroso PJ and Nairn AC et al.. (2005) Regulation of a protein phosphatase cascade allows convergent dopamine and glutamate signals to activate ERK in the striatum. Proc. Natl. Acad. Sci. U.S.A. 102: 491-6 [PMID:15608059]

425. Van Tol HH, Bunzow JR, Guan HC, Sunahara RK, Seeman P, Niznik HB and Civelli O. (1991) Cloning of the gene for a human dopamine D4 receptor with high affinity for the antipsychotic clozapine. Nature $\mathbf{3 5 0}$ : 610-4 [PMID:1840645]

426. Van Tol HH, Wu CM, Guan HC, Ohara K, Bunzow JR, Civelli O, Kennedy J, Seeman P, Niznik HB and Jovanovic V. (1992) Multiple dopamine D4 receptor variants in the human population. Nature 358: 149-52 [PMID:1319557]

427. van Vliet LA, Tepper PG, Dijkstra D, Damsma G, Wikström H, Pugsley TA, Akunne HC, Heffner TG, Glase SA and Wise LD. (1996) Affinity for dopamine D2, D3, and D4 receptors of 2-aminotetralins. Relevance of D2 agonist binding for determination of receptor subtype selectivity. J. Med. Chem. 39: 4233-7 [PMID:8863800]

428. Veruki ML and Wässle H. (1996) Immunohistochemical localization of dopamine D1 receptors in rat retina. Eur. J. Neurosci. 8: 2286-97 [PMID:8950093]

429. Vukhac KL, Sankoorikal EB and Wang Y. (2001) Dopamine D2L receptor- and age-related reduction in offensive aggression. Neuroreport 12: 1035-1038 [PMID:11303741]

430. Wang C, Buck DC, Yang R, Macey TA and Neve KA. (2005) Dopamine D2 receptor stimulation of mitogen-activated protein kinases mediated by cell type-dependent transactivation of receptor tyrosine kinases. J. Neurochem. 93: 899-909 [PMID:15857393]

431. Wang S, Wacker D, Levit A, Che T, Betz RM, McCorvy JD, Venkatakrishnan AJ, Huang XP, Dror RO and Shoichet BK et al.. (2017) D4 dopamine receptor high-resolution structures enable the discovery of selective agonists. Science 358: 381-386 [PMID:29051383]

432. Wang Y, Xu R, Sasaoka T, Tonegawa S, Kung MP and Sankoorikal EB. (2000) Dopamine D2 long receptor-deficient mice display alterations in striatum-dependent functions. J. Neurosci. 20: 8305-14 [PMID:11069937]

433. Waters N, Löfberg L, Haadsma-Svensson S, Svensson K, Sonesson C and Carlsson A. (1994) Differential effects of dopamine D2 and D3 receptor antagonists in regard to dopamine release, in vivo receptor displacement and behaviour. J. Neural Transm. Gen. Sect. 98: 39-55 [PMID:7710738]

434. Waters N, Svensson K, Haadsma-Svensson SR, Smith MW and Carlsson A. (1993) The dopamine D3receptor: a postsynaptic receptor inhibitory on rat locomotor activity. J. Neural Transm. Gen. Sect. 94: 11-9 [PMID:8129881]

435. Watts VJ and Neve KA. (1996) Sensitization of endogenous and recombinant adenylate cyclase by activation of D2 dopamine receptors. Mol. Pharmacol. 50: 966-76 [PMID:8863843]

436. Wedemeyer C, Goutman JD, Avale ME, Franchini LF, Rubinstein M and Calvo DJ. (2007) Functional 
activation by central monoamines of human dopamine $\mathrm{D}(4)$ receptor polymorphic variants coupled to GIRK channels in Xenopus oocytes. Eur. J. Pharmacol. 562: 165-73 [PMID:17350612]

437. Weinshank RL, Adham N, Macchi M, Olsen MA, Branchek TA and Hartig PR. (1991) Molecular cloning and characterization of a high affinity dopamine receptor (D1 beta) and its pseudogene. J. Biol. Chem. 266: 22427-35 [PMID:1834671]

438. Werner P, Hussy N, Buell G, Jones KA and North RA. (1996) D2, D3, and D4 dopamine receptors couple to $G$ protein-regulated potassium channels in Xenopus oocytes. Mol. Pharmacol. 49: 656-61 [PMID:8609893]

439. Westin JE, Vercammen L, Strome EM, Konradi C and Cenci MA. (2007) Spatiotemporal pattern of striatal ERK $1 / 2$ phosphorylation in a rat model of L-DOPA-induced dyskinesia and the role of dopamine D1 receptors. Biol. Psychiatry 62: 800-10 [PMID:17662258]

440. White BH, Kimura K and Sidhu A. (1999) Inhibition of hormonally induced inositol trisphosphate production in Transfected $\mathrm{GH} 4</$ sup $>\mathrm{C} 1$ cells: A novel role for the D5 subtype of the dopamine receptor. Neuroendocrinology 69: 209-16 [PMID:10087453]

441. Xi ZX and Gardner EL. (2007) Pharmacological actions of NGB 2904, a selective dopamine D3 receptor antagonist, in animal models of drug addiction. CNS Drug Rev 13: 240-59 [PMID:17627675]

442. Xi ZX, Gilbert J, Campos AC, Kline N, Ashby Jr CR, Hagan JJ, Heidbreder CA and Gardner EL. (2004) Blockade of mesolimbic dopamine D3 receptors inhibits stress-induced reinstatement of cocaine-seeking in rats. Psychopharmacology (Berl.) 176: 57-65 [PMID:15083257]

443. Xiao J, Free RB, Barnaeva E, Conroy J, Doyle T, Bryant-Genevier M, Taylor MK, Southall N, Hu X and Ferrer $\mathrm{M}$ et al.. (2010) Discovery, optimization, and characterization of a novel series of dopamine D2 versus D3 receptor selective antagonists. Probe Reports from the NIH Molecular Libraries Program [PMID:24260782]

444. Xiao J, Free RB, Barnaeva E, Conroy JL, Doyle T, Miller B, Bryant-Genevier M, Taylor MK, Hu X and Dulcey AE et al.. (2014) Discovery, optimization, and characterization of novel D2 dopamine receptor selective antagonists. J. Med. Chem. 57: 3450-63 [PMID:24666157]

445. Xu M, Caine SB, Cooper DC, Gold LH, Graybiel AM, Hu XT, Loeltzow T, Koob GF, Moratalla R, White FJ and Tonegawa S. (1995) Analysis of dopamine D3 and D1 receptor mutant mice. (Abstract) Soc. Neurosci. Abst. 21: 363-

446. Xu M, Koeltzow TE, Santiago GT, Moratalla R, Cooper DC, Hu XT, White NM, Graybiel AM, White FJ and Tonegawa S. (1997) Dopamine D3 receptor mutant mice exhibit increased behavioral sensitivity to concurrent stimulation of D1 and D2 receptors. Neuron 19: 837-48 [PMID:9354330]

447. Yamada S, Yokoo H and Nishi S. (1994) Differential effects of dopamine agonists on evoked dopamine release from slices of striatum and nucleus accumbens in rats. Brain Res. 648: 176-9 [PMID:7922522]

448. Yamaguchi H, Aiba A, Nakamura K, Nakao K, Sakagami H, Goto K, Kondo H and Katsuki M. (1996) Dopamine D2 receptor plays a critical role in cell proliferation and proopiomelanocortin expression in the pituitary. Genes Cells 1: 253-68 [PMID:9140068]

449. Yan Y, Jiang W, Liu L, Wang X, Ding C, Tian Z and Zhou R. (2015) Dopamine controls systemic inflammation through inhibition of NLRP3 inflammasome. Cell 160: 62-73 [PMID:25594175]

450. Yan Z and Surmeier DJ. (1997) D5 dopamine receptors enhance Zn2+-sensitive GABA(A) currents in striatal cholinergic interneurons through a PKA/PP1 cascade. Neuron 19: 1115-26 [PMID:9390524]

451. Yang Z, Asico LD, Yu P, Wang Z, Jones JE, Bai RK, Sibley DR, Felder RA and Jose PA. (2005) D5 dopamine receptor regulation of phospholipase D. Am. J. Physiol. Heart Circ. Physiol. 288: H55-61 [PMID:15598876]

452. Yang Z, Asico LD, Yu P, Wang Z, Jones JE, Escano CS, Wang X, Quinn MT, Sibley DR and Romero GG et al.. (2006) D5 dopamine receptor regulation of reactive oxygen species production, NADPH oxidase, and blood pressure. Am. J. Physiol. Regul. Integr. Comp. Physiol.290: R96-R104 [PMID:16352863]

453. Yang Z, Sibley DR and Jose PA. (2004) D5 dopamine receptor knockout mice and hypertension.J. Recept. Signal Transduct. Res. 24: 149-64 [PMID:15521360]

454. Yoon S and Baik JH. (2013) Dopamine D2 receptor-mediated epidermal growth factor receptor 
transactivation through a disintegrin and metalloprotease regulates dopaminergic neuron development via extracellular signal-related kinase activation. J. Biol. Chem. 288: 28435-46 [PMID:23955337]

455. Yu C, Yang Z, Ren H, Zhang Y, Han Y, He D, Lu Q, Wang X, Wang X and Yang Cet al.. (2009) D3 dopamine receptor regulation of ETB receptors in renal proximal tubule cells from WKY and SHRs. Am. J. Hypertens. 22: 877-83 [PMID:19390510]

456. Yu PY, Eisner GM, Yamaguchi I, Mouradian MM, Felder RA and Jose PA. (1996) Dopamine D1A receptor regulation of phospholipase $C$ isoform. J. Biol. Chem. 271: 19503-8 [PMID:8702641]

457. Yuen EY, Zhong $P$ and Yan Z. (2010) Homeostatic regulation of glutamatergic transmission by dopamine D4 receptors. Proc. Natl. Acad. Sci. U.S.A. 107: 22308-13 [PMID:21135234]

458. Zajdel P, Marciniec K, Maślankiewicz A, Grychowska K, Satała G, Duszyńska B, Lenda T, Siwek A, Nowak $G$ and Partyka A et al.. (2013) Antidepressant and antipsychotic activity of new quinoline- and isoquinoline-sulfonamide analogs of aripiprazole targeting serotonin $5-\mathrm{HT}_{1} \mathrm{~A} / 5-\mathrm{HT}_{2} \mathrm{~A} / 5-\mathrm{HT}_{7}$ and dopamine $\mathrm{D}_{2} / \mathrm{D}_{3}$ receptors. Eur J Med Chem 60: $42-50$ [PMID:23279866]

459. Zarei S, Frieden M, Rubi B, Villemin P, Gauthier BR, Maechler P and Vischer UM. (2006) Dopamine modulates von Willebrand factor secretion in endothelial cells via D2-D4 receptors. J. Thromb. Haemost. 4: 1588-95 [PMID:16839358]

460. Zhang H, Qiao Z, Zhao $Y$ and Zhao R. (1996) Transcription of dopamine D1A receptor mRNAs in rat heart. Methods Find Exp Clin Pharmacol 18: 183-7 [PMID:8738069]

461. Zhang Y, Fu C, Asico LD, Villar VA, Ren H, He D, Wang Z, Yang J, Jose PA and Zeng C. (2011) Role of $G \alpha(12)$ - and $G \alpha(13)$-protein subunit linkage of $D(3)$ dopamine receptors in the natriuretic effect of $D(3)$ dopamine receptor in kidney. Hypertens. Res. 34: 1011-6 [PMID:21633357]

462. Zhang Y, Jiang X, Qin C, Cuevas S, Jose PA and Armando I. (2016) Dopamine D2 receptors' effects on renal inflammation are mediated by regulation of PP2A function. Am. J. Physiol. Renal Physiol. 310: F12834 [PMID:26290374]

463. Zhang ZW, Burke MW, Calakos N, Beaulieu JM and Vaucher E. (2010) Confocal Analysis of Cholinergic and Dopaminergic Inputs onto Pyramidal Cells in the Prefrontal Cortex of Rodents. Front Neuroanat 4: 21 [PMID:20589096]

464. Zhen J, Antonio T, Dutta AK and Reith ME. (2010) Concentration of receptor and ligand revisited in a modified receptor binding protocol for high-affinity radioligands: [3H]Spiperone binding to D2 and D3 dopamine receptors. J. Neurosci. Methods 188: 32-8 [PMID:20122961]

465. Zhen X, Uryu K, Wang HY and Friedman E. (1998) D1 dopamine receptor agonists mediate activation of p38 mitogen-activated protein kinase and c-Jun amino-terminal kinase by a protein kinase A-dependent mechanism in SK-N-MC human neuroblastoma cells. Mol. Pharmacol. 54: 453-8 [PMID:9730903]

466. Zhong P and Yan Z. (2016) Distinct Physiological Effects of Dopamine D4 Receptors on Prefrontal Cortical Pyramidal Neurons and Fast-Spiking Interneurons. Cereb. Cortex 26: 180-91 [PMID:25146372]

467. Zhou QY, Grandy DK, Thambi L, Kushner JA, Van Tol HH, Cone R, Pribnow D, Salon J, Bunzow JR and Civelli O. (1990) Cloning and expression of human and rat D1 dopamine receptors. Nature 347: 76-80 [PMID:2168520] 